\title{
Structural style and neotectonic activity along the Harz Boundary Fault, northern Germany: a multimethod approach integrating geophysics, outcrop data and numerical simulations
}

\author{
Katharina Müller ${ }^{1} \cdot$ Ulrich Polom ${ }^{2}$. Jutta Winsemann ${ }^{1} \cdot$ Holger Steffen $^{3}$ (D) Sumiko Tsukamoto ${ }^{2}$. Thomas Günther ${ }^{2}$. \\ Jan Igel $^{2} \cdot$ Thomas Spies $^{4} \cdot$ Thomas Lege $^{4} \cdot$ Manfred Frechen $^{2} \cdot$ Hans-Joachim Franzke $^{5} \cdot$ Christian Brandes $^{1}$
}

Received: 28 June 2019 / Accepted: 9 May 2020 / Published online: 30 May 2020

(C) The Author(s) 2020

\begin{abstract}
We present new evidence for neotectonic activity along the Harz Boundary Fault, a Cretaceous reverse fault that represents a key structure in northern Germany. For the fault analysis, we use a multimethod approach, integrating outcrop data, luminescene dating, shear wave seismics, electrical resistivity tomography (ERT) and numerical simulations. A recent sinkhole at the SSW-ward dipping and WNW-ESE striking Harz Boundary Fault exposes a NNE-ward dipping and WNW-ESE striking planar fault surface that cuts through unconsolidated debris-flow deposits thus pointing to young Lateglacial tectonic activity. The fault shows a polyphase evolution with initial normal fault movement and a later reactivation as an oblique fault with reverse and strike-slip components. A shear wave seismic profile was acquired to analyse the geometry of the fault and show that the Harz Boundary Fault is steeply dipping and likely has branches. Partly, these branches propagate into overlying alluvial-fan deposits that are probably Pleniglacial to Lateglacial in age. The outcrop data in combination with the seismic data give evidence for a splay fault system with steep back-thrusts. One of these back-thrusts is most likely the NNE-ward dipping fault that is exposed in the sinkhole. The lateral extent of the fault was mapped with electrical resistivity tomography (ERT) profiles. The timing of fault movement was estimated based on optically stimulated luminescence dating of the faulted debris-flow deposits using both quartz and feldspar minerals. Consistent feldspar and quartz ages indicate a good bleaching of the sediment prior to deposition. The results imply fault movements post-dating $\sim 15 \mathrm{ka}$. Numerical simulations of glacio isostatic adjustment (GIA)-related changes in the Coulomb failure stress regime at the Harz Boundary Fault underpin the assumption that the fault was reactivated during the Lateglacial due to stress changes induced by the decay of the Late Pleistocene (Weichselian) Fennoscandian ice sheet.
\end{abstract}

Keywords Harz Boundary Fault · Neotectonics · Northern Germany · Glacial isostatic adjustment (GIA) · Electrical resistivity tomography $($ ERT) $\cdot$ Shear wave seismics $\cdot$ Luminescence dating $\cdot$ Numerical simulations $\cdot$ Lateglacial

Electronic supplementary material The online version of this article (https://doi.org/10.1007/s00531-020-01874-0) contains supplementary material, which is available to authorized users.

Katharina Müller

mueller@geowi.uni-hannover.de

1 Institut für Geologie, Leibniz Universität Hannover, Callinstr. 30, 30167 Hannover, Germany

2 Leibniz Institute for Applied Geophysics (LIAG), Stilleweg 2, 30655 Hannover, Germany

3 Lantmäteriet, Geodetic Infrastructure, Referenssystem, Lantmäterivägen 2C, 80102 Gävle, Sweden
4 Bundesanstalt für Geowissenschaften und Rohstoffe (BGR), Stilleweg 2, 30655 Hannover, Germany

5 Institut für Geologie und Paläontologie, Technischen Universität Clausthal, Leibnizstraße 10, 38678 Clausthal-Zellerfeld, Germany 


\section{Introduction}

The analysis of the neotectonic activity of northern Germany is challenging, because fault scarps that could point to past seismic events are rarely developed due to the low slip rates and climate conditions (Kaiser 2005). In general, this region is commonly regarded as a low seismicity area (Leydecker and Kopera 1999). However, there is evidence for several seismic events during the last 1200 years (Leydecker 2011). In addition, the palaeoseismological studies that were carried out in northern Germany (e.g., Hübscher et al. 2004; Brandes and Tanner 2012; Hoffmann and Reicherter 2012; Brandes et al. 2011, 2012; Brandes and Winsemann 2013; Brandes et al. 2018a; Pisarska-Jamroży et al. 2018, 2019; Grube 2019a, b) also point to a higher seismic activity than previously thought. Al Hseinat and Hübscher (2017) recently found faults in the Baltic Sea, which dissect Pleistocene deposits and therefore point to young tectonic activity. This questions the status of a low seismicity area and its earthquake hazard. For a profound seismic hazard assessment, it is thus necessary to re-evaluate the past seismic activity and tectonic movements as well as the probability of earthquakes in northern Germany.

Collisional forces from the Alpine orogeny and the Atlantic ridge push affect the stress field in northern Germany (Marotta et al. 2001, 2002, 2004; Kaiser et al. 2005). Evidence for active faults in northern Germany is rare but recent tectonic earthquakes were recorded e.g., east of Hamburg in 2000 (magnitude of $M_{\mathrm{w}} 3.1$; Bock et al. 2002) and in the Leipzig/Halle area in 2015 and 2017 (magnitude of $M_{\mathrm{w}} 3.2$ and 2.8; Dahm et al. 2018). Many of the historic earthquakes concentrate along major Cretaceous reverse faults and were possibly triggered by lithospheric stress changes due to glacial isostatic adjustment (Brandes et al. 2015). The approximately $90 \mathrm{~km}$ long Harz Boundary Fault (Fig. 1) is one of these Cretaceous reverse faults and represents a key structure in northern Germany. There is a controversial discussion about the nature of the Harz Boundary Fault. Two different interpretations co-exist, a wrench fault system and a frontal thrust model (Wrede 1988, 2008, 2009 and Voigt et al. 2009). The frontal thrust model is meanwhile well supported by field evidence from investigations along the Harz Boundary Fault (Flick 1986; Franzke et al. 1995; Kley et al. 2008). More recently, Paul (2019) discussed the role of dissolution and migration of Zechstein salt for basin-wide subsidence and uplift in the Harz foreland area and the Harz Mountains.

The aim of this study is to visualize the structural style of the fault zone at the northern Harz boundary with shear wave seismic and electrical resistivity tomography (ERT) profiles and to analyse the neotectonic activity of the fault.
Tectonic evidence of young fault movements along the Harz Boundary Fault were already published by Franzke et al. (2015). The study benefits from a recent sinkhole at the Harz Boundary Fault, which exposes a NNE-ward dipping and WNW-ESE striking planar fault plane with several slip surfaces that cuts through unconsolidated debrisflow deposits (Franzke et al. 2015). In this study, we use an expanded dataset. We image the faults in a shear wave seismic profile and mapped the lateral extent of the fault in the sinkhole using electrical resistivity tomography (ERT) profiles. We estimate the timing of fault activity by means of luminescence dating of faulted periglacial debris-flow deposits and use numerical simulations of glacial isostatic adjustment (GIA)-related changes of Coulomb failure stress to support the estimated ages.

\section{Geological setting}

The study area is located in northern Germany and belongs to the Subhercynian Basin, which lies directly north of the Harz Mountains and forms a subbasin of the Central European Basin System (CEBS) (Fig. 1a, b). The geological evolution of northern Germany is characterized by different tectonic processes (Lohr et al. 2007; Kley et al. 2008). In Permian and Triassic times, E-W transtension/ extension took place, which was followed by NNE-SSW extension in the Jurassic to Early Cretaceous. The Late Cretaceous is characterized by an NE-SW to NNE-SSW compression. The Late Cretaceous contraction lasted into the Paleogene (Lohr et al. 2007). This led to crustal shortening in the study area and as a result, local thrust-related basement uplifts such as the Flechtingen High and the Harz Mountains formed. In addition, a widespread reactivation of faults occurred. This tectonic inversion phase was discussed in detail by Baldschuhn et al. (1991), Kockel (2003), Kley and Voigt (2008) and Kley et al. (2008).

\section{The Harz Boundary Fault and the Subhercynian Basin}

A key element of the Late Cretaceous inversion phase and intraplate deformation in northern Germany is the Harz Boundary Fault that separates the Palaeozoic rocks of the Harz Mountains from the Mesozoic sedimentary rocks of the Subhercynian Basin (von Eynatten et al. 2008; Voigt et al. 2008) (Fig. 1c). Modelling results of Kaiser et al. (2005) predict a modern fault slip rate of $0.08 \mathrm{~mm} /$ year for the Harz Boundary Fault. The Subhercynian Basin trends WNW-ESE and is approximately $100 \mathrm{~km}$ long and $50 \mathrm{~km}$ wide. It is bounded to the SSW by the Harz Boundary Fault and to the NNE by the Flechtingen basement high (Stackebrandt 1986). The basin has a twofold evolution that started with extensional movements in the early Permian. Extension prevailed 

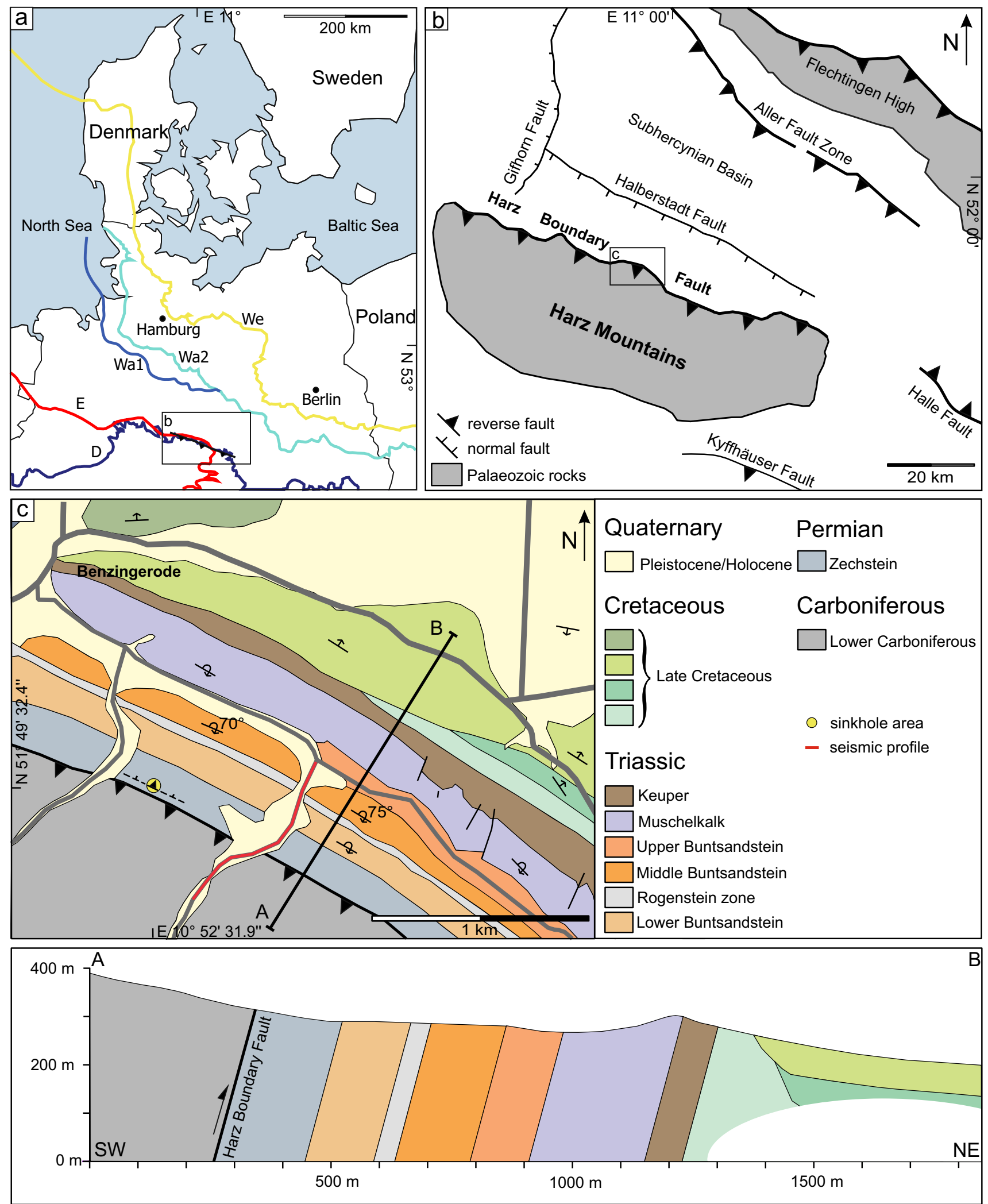

Fig. 1 Location of the study area in northern Germany; a maximum extents of the Elsterian (E), Saalian (D: Drenthe; Wa1: Warthe 1 and Wa2: Warthe 2) and Weichselian (We) ice sheets are shown in red, light- and dark-blue and yellow (modified after Ehlers et al. 2011;
Roskosch et al. 2015; Lang et al. 2018; Winsemann et al. 2020); b close-up view of the study area showing major fault systems; $\mathbf{c}$ geological map of the study area with geological cross-section (modified after Schröder et al. 1927) 
throughout the Mesozoic. In Late Cretaceous times, the Subhercynian Basin was transformed into a kind of foreland basin controlled by the overthrusting of the Harz basement block (Franzke et al. 2004; Voigt et al. 2006; Kley et al. 2008; Brandes et al. 2013; Tanner and Krawczyk 2017).

\section{Pleistocene deposits}

During the Pleistocene, northern Germany was influenced by three major ice advances referred to as the Elsterian, Saalian and Weichselian glaciations. The Harz foreland was affected by the Elsterian and Saalian glaciations (Fig. 1a; Reinecke 2006; Ehlers et al. 2011; Lang et al. 2018, 2019). The Elsterian ice advances probably reached the study area during Marine Isotope Stages MIS 12 and 10 (Roskosch et al. 2015), leaving meltwater sediments and two Elsterian tills (Feldmann 2002; Elsner 2003; Lang et al. 2012). Subsequently fluvial sediments were deposited (Weymann et al. 2005; Reinecke 2006). These fluvial deposits are covered by Saalian glacigenic sediments (Weymann et al. 2005), which are probably MIS 6 in age (Litt et al. 2007; Lang et al. 2018, 2019).

During the Late Pleistocene Weichselian glaciation, the ice sheets did not cross the Elbe River (Ehlers et al. 2011) and periglacial conditions prevailed in northwestern and central Germany (Reinecke 2006; Kasse et al. 2007; Litt et al. 2007; Meinsen et al. 2014; Lehmkuhl et al. 2016). Periglacial Late Pleniglacial to Lateglacial deposits in the study area consist of alluvial, mass-flow and aeolian deposits (Fig. 2) (Bode et al. 2003; Weymann et al. 2004; Reinecke 2006; Litt and Wansa 2008; Krauß et al. 2016; Lehmkuhl et al. 2016). On hillslopes, different mass-flow deposits accumulated that are commonly referred to as periglacial cover beds ("periglaziale Deckschichten"; Reinecke 2006; Litt and Wansa 2008). These periglacial massflow deposits are generally subdivided into three main depositional units referred to as basal layer ("Basislage"), middle layer ("Mittellage") and main layer ("Hauptlage") (Reinecke 2006; Litt and Wansa 2008; Bullmann 2010). The basal layer directly overlies bedrock and is commonly characterized by a high clast content. The middle layer is partly rich in reworked loess. The main layer forms the top of these periglacial mass-flow deposits and may contain Laacher See tephra. The main layer is partly overlain by loess (Fig. 2). However, not all depositional units are always present. In general, the age of these mass-flow deposits is poorly constrained and based on an uncertain correlation with dated deposits of the Harz foreland area (Fig. 2; Reinecke 2006; Litt and Wansa 2008; Bullmann 2010). The main layer probably formed during the younger Dryas, as indicated by the presence of reworked Laacher See tephra (Reinecke 2006; Bullmann 2010), which is a marker horizon for the late Allerød (van den Bogaard 1995; Reinecke 2006). During the Holocene, a stabilizing vegetation cover rapidly formed on hillslopes (Litt et al. 2007), preventing further mass-flow events.

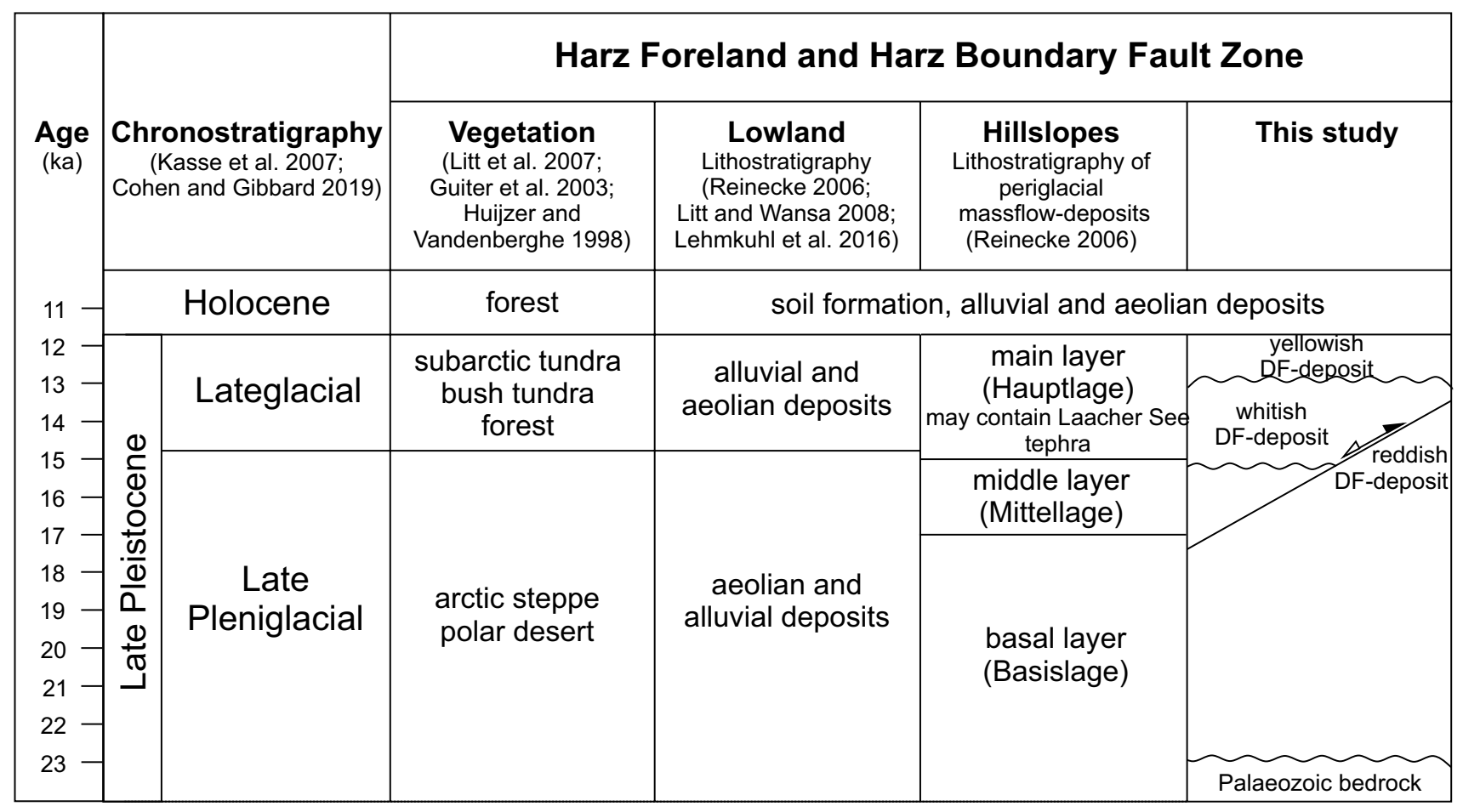

Fig. 2 Stratigraphy of Late Pleistocene periglacial deposits. DF Debris flow 


\section{Sinkholes}

At the southern margin of the Subhercynian Basin, north of the Harz Boundary Fault, several sinkholes occur due to dissolution processes in the steeply dipping sulphate rocks that belong to the Zechstein Werra sequence (Schröder and Dahlgrün 1927; Franzke et al. 2015). Approximately $30 \mathrm{~m}$ north of the Harz Boundary Fault a recent sinkhole (likely developed around the year 2013) (N51 ${ }^{\circ} 49^{\prime} 32.4^{\prime \prime} \mathrm{E} 10^{\circ} 52^{\prime}$ 31.9"), exposes a NNE-ward dipping and WNW-ESE striking planar fault plane with several slip surfaces (Figs. 1c, 3). This fault displaces two debris-flow deposits that differ in colour and composition (Fig. 3). The fault tip is sealed by a younger thin debris-flow deposit.

\section{Methods}

This study is based on outcrop data, electrical resistivity tomography (ERT) profiles, a high-resolution shear wave seismic profile, luminescence dating, and numerical simulations. Field work included sedimentological and structural analyses of outcrops and sampling for luminescence dating (Fig. 3a). The luminescence dating was performed at the Leibniz Institute for Applied Geophysics (LIAG).

\section{Electrical resistivity tomography (ERT)}

Four electrical resistivity tomography (ERT) profiles were acquired to map the lateral extent of the NNE-dipping fault exposed in the sinkhole. The ERT method is very suitable to detect near-surface faults (e.g., Caputo et al. 2003; Vanneste 2008; Gélis et al. 2010).

The profiles are $40 \mathrm{~m}$ (profile 1) and $30 \mathrm{~m}$ (profiles 2, 3,4 ) long and trend $\sim \mathrm{NE}-\mathrm{SW}$, perpendicular to the Harz Boundary Fault and to the fault in the sinkhole (Fig. 4). Profiles 1-3 were measured NW of the sinkhole. Profile 4 was measured SE of the sinkhole (Fig. 4). Electrodes were spaced at a distance of $0.5 \mathrm{~m}$ to resolve small and shallow structures. GPS positions of the electrodes were acquired using a total station and provided accurate elevations for the inversion process that reconstructs the subsurface resistivity. To incorporate the rough topography, we used the finite-element method with an irregular triangle mesh implemented in the software BERT (Günther et al. 2006).

For the ERT measurements, we applied the dipole-dipole array that provides the best resolution and the Wenner array for deep penetration. We combined several base dipole lengths ( $a=1,2,4$ and 8) and dipole separations of $n=1$ through 6 . The resulting high-quality data could be fitted with root-mean-square errors between 2 and $4 \%$.

Samples were taken from debris-flow DF-1 and DF-2 to measure their resistivities in the laboratory. The sediments were inserted in a sample holder and measured under different water saturations using a 4-point light $10 \mathrm{~W}$ Lippmann device.

\section{Shear wave seismics}

One shear wave seismic reflection profile was acquired to analyse the shallow subsurface structure of the Harz Boundary Fault zone in high resolution. The profile is approximately $1 \mathrm{~km}$ long and oriented perpendicular to the Harz Boundary Fault (Figs. 1c, 4). The shear wave vibroseis method (Crawford et al. 1960; Ghose et al. 1996; Polom et al. 2013), using a linear frequency modulated seismic source signal of $20-160 \mathrm{~Hz}$ over $10 \mathrm{~s}$ duration, was applied. For a fast data acquisition in high resolution, a land streamer unit with 120 transverse horizontal (SH) geophones $(10 \mathrm{~Hz}$ resonance frequency) at $1 \mathrm{~m}$ interval and an electrodynamicdriven SH shaker source system was used (Polom et al. 2011). The achieved maximum target depth of the SH waves is nearly $70 \mathrm{~m}$. The recording configuration was a so-called asymmetric varying split-spread setup. Two sweeps with alternating polarity were initiated at each source location.

In contrast to the commonly used compression waves (P-waves) of exploration seismics, shear waves only propagate in solid material. Shear waves cannot propagate in liquids or gases of the pore space, where the shear modulus is zero. Therefore, e.g., the groundwater level does not affect the shear wave propagation, resulting in significantly lower velocities and an improved resolution compared to $P$ waves. On the other hand, as result of the low velocities, the penetration depth is significantly lower compared to $\mathrm{P}$ waves.

The acquired seismic data underwent a standard processing procedure using the VISTA software (version 10.028, Schlumberger). During the processing, first a quality assessment, a geometry fitting and a vibroseis correlation were carried out. The next steps of the processing procedure were the vertical stacking of records, an automatic gain control for amplitude scaling and the application of band pass and frequency-wavenumber (FK) filters. Afterwards interactive velocity analysis, common mid-point (CMP) stacking, and a finite-difference (FD) time migration were applied. The last step of the processing was the time-to-depth conversion using a data-driven $2 \mathrm{D}$ velocity function.

\section{Sampling}

Seven samples were taken from the faulted sediments, which are exposed in the sinkhole (N51 $\left.{ }^{\circ} 49^{\prime} 32.4^{\prime \prime} \mathrm{E} 10^{\circ} 52^{\prime} 31.9^{\prime \prime}\right)$, close to the Harz Boundary Fault (Figs. 1c, 3). In general, debris-flow deposits are difficult to date (e.g., Döhler et al. 2018), especially carbonate-rich debris-flows that are poor in quartz and feldspar minerals. Therefore, as many samples 

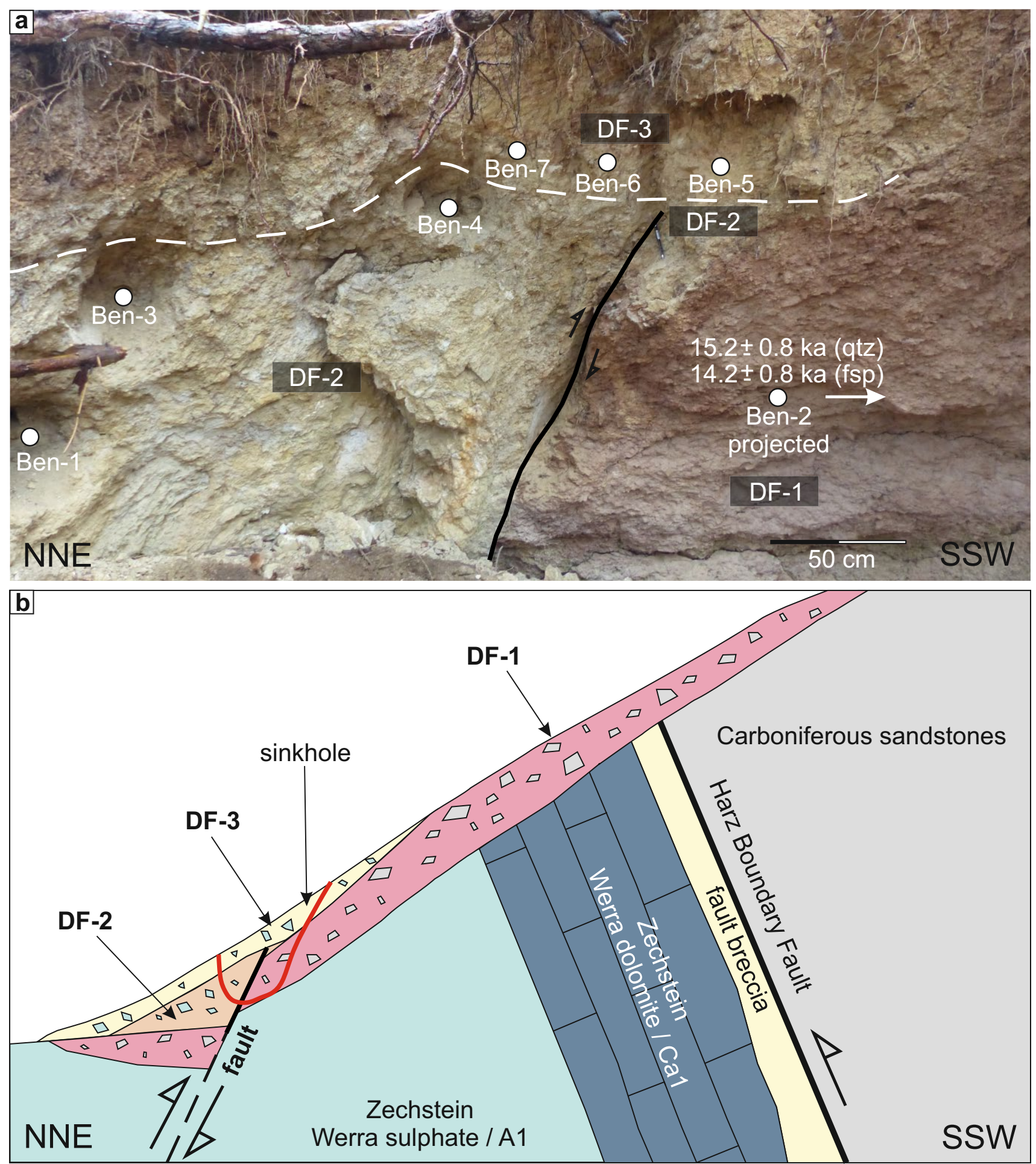

Fig. 3 Sinkhole above the Zechstein Werra-evaporites; a fault surface in Lateglacial debris-flow deposits and location of OSL samples; b schematic profile of the Harz Boundary Fault zone near Benzingerode with the location of the sinkhole (based on Franzke et al. 2015)

as necessary were taken to obtain a good coverage of the debris-flow deposits.

One sample (Ben-2) was taken from the basal reddish debris-flow (DF-1) in the footwall south of the exposed fault trace. Three more samples (Ben-1, Ben-3, Ben-4) are derived from the hanging-wall block north of the fault surface (lower whitish debris-flow deposit; DF-2). Three further samples (Ben-5, Ben-6, Ben-7) were taken from the 


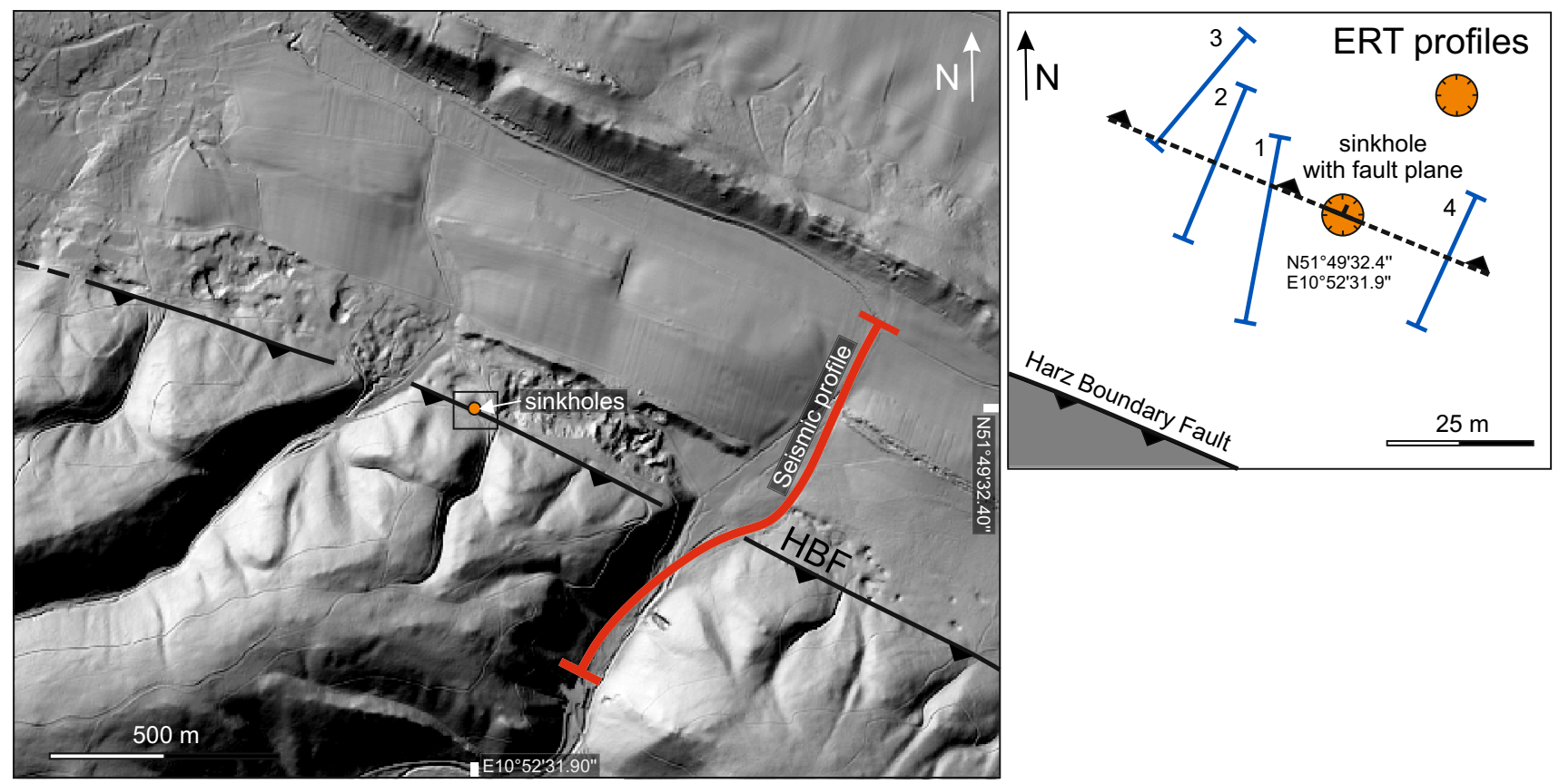

Fig. 4 Hill-shaded relief model of the study area showing the Harz Boundary Fault (HBF) (between the localities of Benzingerode and Heimburg), seismic and ERT profiles and the sinkhole location. The

yellowish debris-flow (DF-3) that seals the fault tip (Fig. 3a). The sample material of Ben-1 was too coarse-grained for luminescence dating and thus not enough material of the required grain-size was obtained during sample preparation.

During the sampling procedure, opaque metal tubes with a length of $10 \mathrm{~cm}$ and a diameter of $5 \mathrm{~cm}$ were hammered into the freshly cleaned sediment surface and closed with aluminum foil to avoid light exposure. Additionally, samples $(700 \mathrm{~g})$ for dose rate determination were taken from the surrounding sediment at each sample position.

\section{Luminescence dating}

For age determination of the fault movements, we performed luminescence dating on fine-grained $(4-11 \mu \mathrm{m})$ quartz minerals and polymineralic material for feldspar measurements. Additional technical information about the method is given in the supplementary files.

\section{Numerical simulations}

To analyse the glacially induced fault reactivation potential, numerical simulations were carried out in form of three-dimensional (3D) finite-element (FE) simulations that describe the process of GIA together with Coulomb failure stress (CFS) calculations. Input parameters to a GIA model are generally (i) the Earth's structure and rheology in the subsurface down to the core-mantle boundary and
DEM is based on data from the Landesamt für Vermessung und Geoinformation Sachsen-Anhalt (GeoBasis-DE/LVermGeo LSA, 2016) (1 m grid, vertical resolution: $\pm 0.2 \mathrm{~m}$ )

(ii) the ice load history of the last glaciation. Our models are based on the flat-Earth approach described Wu (2004), Steffen et al. (2006) and Brandes et al. (2018b). The FE software ABAQUS (ABAQUS 2018) is applied to create a 3D earth model with a size of $60,000 \mathrm{~km} \times 60,000 \mathrm{~km}$ (horizontally) $\times 2891 \mathrm{~km}$ (depth to core-mantle boundary). A centre block of $4500 \mathrm{~km} \times 4500 \mathrm{~km} \times 2891 \mathrm{~km}$ size represents our study area, the lithosphere and mantle of Fennoscandia, while the frame allows mantle material to flow outside this area minimizing any associated numerical errors (Steffen et al. 2006). The element mesh in the centre has $50 \mathrm{~km}$ horizontal side length, while the frame has increasing side lengths from the centre to the edge to save run time and memory. In the vertical the model is subdivided in 18 layers of different thickness, whereas (model-dependent) 8 or 9 element layers build up the elastically behaving lithosphere. Here, the first six layers have $5 \mathrm{~km}$ thickness each for a more detailed analysis of the stress changes in the upper lithosphere. The visco-elastically behaving upper mantle down to $670 \mathrm{~km}$ has four or five element layers, and the lower mantle down to $2891 \mathrm{~km}$ depth five element layers. The Preliminary Reference Earth Model (PREM; Dziewonski and Anderson 1981) is applied to assign layer-dependent and volume-averaged values for density, shear modulus and Young's modulus. For further details, we refer the reader to Brandes et al. (2018b). Rigid boundary conditions fix the sides of the model. An ice history model is applied as ice thickness 
variations over the last two glacial cycles on the element surfaces of the earth model centre.

The setups of the ice and earth model partly affect the results. To show the spread of possible results that may lead to a range of uncertainties of the modelling, we test a variety of Earth and ice model combinations that are based on results of previous GIA studies, which represent the GIA process in Fennoscandia reasonably well.

The timing of possible fault reactivation depends on the Earth model composition according to previous studies (Brandes et al. 2012, 2015, 2018b; Steffen et al. 2014b). Two types of models, with and without a laterally homogeneous structure, are used for numerical simulation. Laterally homogeneous models (i.e., they vary only with depth) are commonly used in GIA modelling. The basic model with laterally homogeneous structure has a lithospheric thickness of $90 \mathrm{~km}$, an upper mantle viscosity of $5 \times 10^{20} \mathrm{~Pa} \mathrm{~s}$ and a lower mantle viscosity of $2 \times 10^{21} \mathrm{~Pa} \mathrm{~s}$, but we additionally tested models that vary in one of these 3 parameters. Hence, we analysed four laterally homogeneous models. We also applied $140 \mathrm{~km}$ lithospheric thickness, $8 \times 10^{20} \mathrm{~Pa}$ s upper mantle viscosity and $2 \times 10^{22} \mathrm{~Pa}$ s lower mantle viscosity. All values represent viable estimates based on GIA studies of Fennoscandia (Lambeck et al. 2010; Zhao et al. 2012; Kierulf et al. 2014). Although these laterally homogeneous models can explain the GIA process in Fennoscandia well, they are not supported by seismic results that point to lateral variations in the deep subsurface. We thus additionally tested two models with a laterally heterogeneous structure. The models vary in lithospheric thickness (90 and $140 \mathrm{~km}$ ) and use a three-dimensional (3D) mantle viscosity structure, which is converted from the seismic tomography model by Grand et al. (1997) based on the method in Wu et al. (2013). For the ice load history part, two different ice history models were used that are available to us and that are commonly applied in GIA studies. The first is the North-European part of the global ice model ICE-6G_C (Argus et al. 2014; Peltier et al. 2015) while the other is a combination of the so-called ANU-ICE history models for the British Isles (Lambeck 1995) and Fennoscandia (Lambeck et al. 2010).

For each model combination, we calculate deformation and stress changes due to GIA with the FE software following the procedure outlined in $\mathrm{Wu}$ (2004). Then, we combine the GIA-induced stress changes with overburden and tectonic background stress to calculate the change in CFS $(\delta C F S)$ for the location of our study area. We test a compressional (thrust/reverse) stress regime for all GIA models. The CFS can be regarded as the simplest form of indication of possible reactivation of a fault as it represents the minimum stress required to reach faulting. Steffen et al. (2014a) found that the crust was critically stressed before glaciation, which means that the CFS was about $0 \mathrm{MPa}$ at that time. Hence, the $\delta \mathrm{CFS}$, which is calculated relative to the CFS before glaciation, shows that a fault is stable when $\delta \mathrm{CFS}$ is negative, while positive values indicate fault instability and potential fault movements. A $\delta$ CFS value of $0 \mathrm{MPa}$ (a zero line) thus represents the threshold that separates zones of instability ( $>0 \mathrm{MPa})$ and stability ( $<0 \mathrm{MPa})$. We apply a CFS of $0 \mathrm{MPa}$ before glaciation and optimally oriented faults, i.e., their strike and dip values promote faulting for a commonly used friction coefficient of 0.6 . For a compressional stress regime, strike values are thus perpendicular to the maximum horizontal direction of the chosen tectonic background stress, while the corresponding optimal fault dip is approximately $30^{\circ}$, respectively. We note that the Harz Boundary Fault strikes about WNW-ESE, which is almost in line with the maximum horizontal principal stress that is suggested from the World Stress Map (Heidbach et al. 2016). Therefore, the fault cannot be initially considered as optimally oriented for the tectonic background regime. However, GIA stresses can overprint tectonic stress fields and lead to rotation of principal stress directions (Wu 1997) so that a fault orientation close to optimal is possible. This is especially the case for small differences in the horizontal components of the principal stresses (Wu 1997) and thus important to consider for faults near the surface since GIA generates additional stresses of some $10 \mathrm{MPa}$ (Wu 1997) contributing here largely to the overall stress budget.

Non-optimally oriented faults could also be activated under certain conditions. This is not part of this investigation, i.e., as this involves testing a large set of parameter combinations (strike and dip of the fault, depth, principal stress directions and their stress differences, friction parameter, pore fluid factor) and is thus left for future studies. We investigate the $\delta \mathrm{CFS}$ at a depth of $12.5 \mathrm{~km}$ for a thrust fault regime.

\section{Results}

\section{Sedimentology}

The sinkhole, in which the fault is exposed, formed in the steeply dipping Zechstein Werra-sulphates that belongs to the Zechstein Z1 sequence (Schröder et al. 1927; Franzke et al. 2015), approximately $30 \mathrm{~m}$ north (Figs. 1c, 4) of the Harz Boundary Fault. The position of the Harz Boundary Fault is taken from the geological map (scale 1:25 000) (Schröder et al. 1927). According to Schröder and Dahlgrün (1927), the position of the Zechstein rocks can be determined with high accuracy and are almost overlain by debris-flow deposits in this area. The sinkhole has a depth of $2 \mathrm{~m}$ and a diameter of $3 \mathrm{~m}$ and exposes three different debris-flow deposits (Fig. 3a), which differ in color, matrix and clast composition (Fig. 5a-c). 

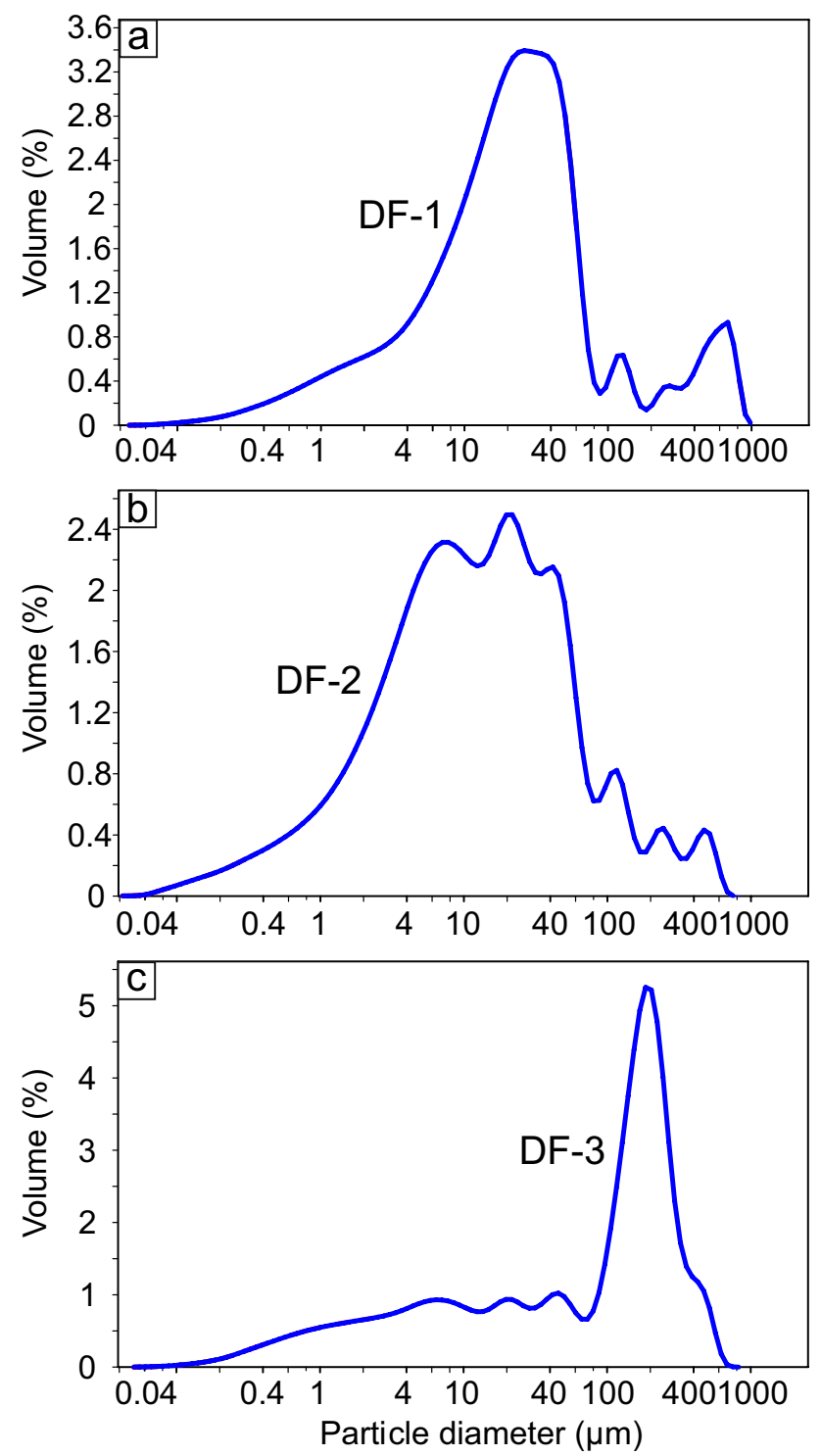

Fig. 5 Grain-size distribution curves of the debris-flow matrix; a basal reddish debris-flow (DF-1; sample Ben-2); b whitish debrisflow (DF-2; sample Ben-3); c yellowish debris-flow (DF-3; sample Ben-6) that seals the tip of the fault

The basal debris-flow deposit (DF-1) has a reddish silty matrix (Fig. 5a) and contains $60-70 \%$ angular greywacke clasts. This reddish debris-flow deposit is overlain by a whitish debris-flow deposit (DF-2) that contains $80 \%$ angular Zechstein clasts, embedded in a silty carbonaceous matrix (Fig. 5b). These two debris-flow deposits are displaced by the fault and are overlain by a yellowish debris-flow deposit (DF-3) that is $\sim 30 \mathrm{~cm}$ thick and seals the fault. This uppermost debris-flow deposit has a silty to fine-grained sandy carbonaceous matrix (Fig. 5c) and contains $20 \%$ angular Zechstein clasts.

\section{Structural geology}

In the lower two debris-flow deposits (DF-1 and DF-2), a NNE-ward dipping and WNW-ESE striking planar fault is developed (Figs. 3, 6). The limited outcrop situation in the sinkhole does not allow to determine the exact offset along the fault. The normal offset of the reddish debris-flow (DF1) must have been at least $150 \mathrm{~cm}$, because the hanging wall is not exposed in the sinkhole (Fig. 3). This normal fault offset was not fully compensated by the later reverse offset of the fault. At least $150 \mathrm{~cm}$ of normal offset remain after the reverse motion.

The fault is characterized by two small bends that separate the fault surface into three segments. The lower segment has an average dip of $76^{\circ}$ and the middle segment has an average dip of $60^{\circ}$. In contrast, the upper segment shows a much steeper dip angle of $80^{\circ}$ (Fig. 6c). Two sets of striations are developed on the fault surface (Fig. 6a, b). These striations indicate initial normal fault movements and a later reactivation of the fault as oblique fault with reverse and strike-slip components (Fig. 6a, b). Similar fault kinematics of this fault were described by Franzke et al. (2015). The tip of the fault is sealed by the third yellowish debris-flow deposit (DF-3). The outcrop reveals that the fault has a complex structure, with a $7-9 \mathrm{~cm}$ thick core that contains several thin slip surfaces, which are characterized by polished and striated surfaces (Figs. 6d, 7), similar to fault cores shown in e.g., Faulkner et al. (2011) or Shipton and Cowie (2003). In addition, the fault core is partly flanked by an alteration halo (Fig. 6d). This alteration halo can be interpreted as part of the fault damage zone, which contains near-field faultrelated deformation (Vermilye and Scholz 1998; Shipton and Cowie 2003). The damage zone is likely the product of fault processes (cf. Kim et al. 2004).

\section{Electrical resistivity tomography (ERT)}

Laboratory measurements show that the debris-flow material from the outcrop has high resistivities (1200 $\Omega \mathrm{m}$ for DF-1 and $2000 \Omega \mathrm{m}$ for DF-2). This is caused by the very low water content of the samples (3-5 vol-\%) due to the drying of the debris-flow deposits during the summer. As moisture was far below the expected in-situ conditions, we added some water to the samples resulting in about $20 \mathrm{vol} \%$ water. We then obtained similar resistivities slightly below $20 \Omega \mathrm{m}$ for both DF-1 and DF-2, so that they cannot be distinguished from each other. This is probably caused by their similar grain-size distribution and mineral composition. However, we expect secondary effects in electrical resistivity in the vicinity of the fault zone due to shearing or fracturing processes, which leads to variations in the porosity and thus to the water saturation of the deposits. Deposits with high porosity and thus a low water content are indicated by high 

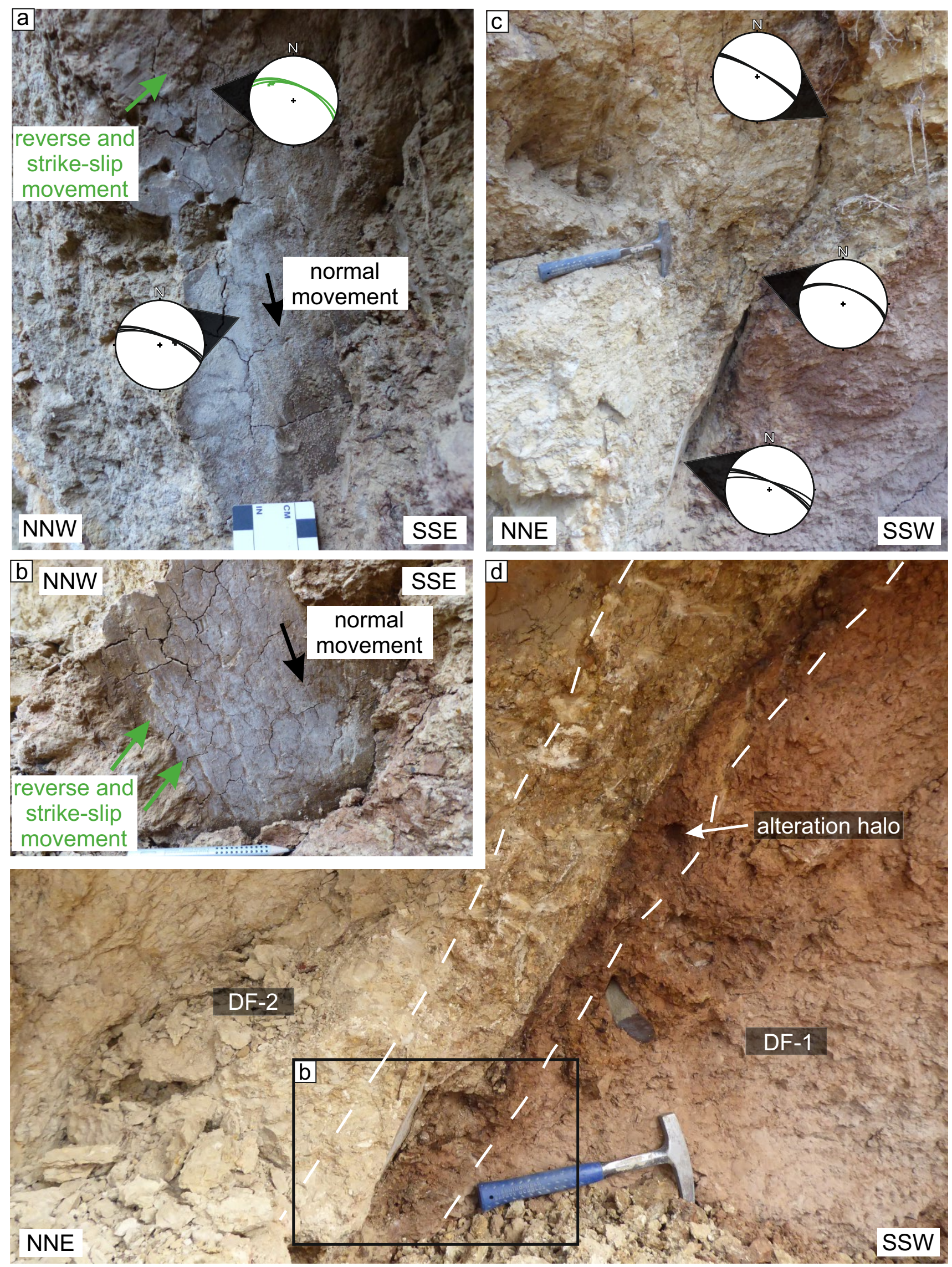
4Fig. 6 Structural data set of the exposed NNE-ward dipping fault in the sinkhole; a stereographic projections showing normal and oblique reverse fault kinematics; b fault surface with normal and oblique reverse kinematics; $\mathbf{c}$ stereographic projections of the normal fault component; $\mathbf{d}$ fault surface in debris-flow deposits with fault core and alteration halo

resistivities, whereas deposits with low porosity and higher water content show low resistivities. Furthermore, we expect a contrast to the underlying Zechstein sulphates (gypsum), which resistivity is expected to be higher ( $>150 \Omega \mathrm{m}$ for undissolved and 50-100 $\Omega \mathrm{m}$ for moderately dissolved gypsum according to Drahor (2019).

\section{Interpretation}

The basal parts of all profiles are characterized by low electrical resistivities, which are probably caused by a relatively high water content (cf. Ullrich et al. 2008) of debris-flow deposits DF-1 and DF-2, which have a fine-grained silty matrix (Fig. 5a, b). The central zone of higher resistivity $(\sim 60-130 \Omega \mathrm{m})$ runs parallel to the strike direction of the small NNE-ward dipping fault that is exposed in the sinkhole. We interpret this resistivity pattern (mostly visible on profiles 1 and 4) as the offset Zechstein sulphate (gypsum) that is located 3-4 m below the surface (see schematic profile of Fig. 3b), whereas it is hardly detectable on profiles 2 and 3 . The initial normal movements brought the hanging-wall block north of the fault in a position below the penetration depth of the ERT. The near-surface part of the fault is characterized by a complex structure with a several centimetre-thick alteration halo and a fault core that contains several parallel slip surfaces (Figs. 6d, 7). This heterogeneity is probably reflected in the resistivity pattern. The part of the higher resistivities $(\sim 60-130 \Omega \mathrm{m})$ may represent the fault core that is characterized by sheared finer grained material with less fractures and voids that are not completely water-saturated.

The alteration halo likely has a higher water content caused by a higher fracture density. Therefore, the surrounding lower resistivity values (30-60 $\Omega \mathrm{m})$ are interpreted as the flanking fault damage zone (Fig. 8).

The high electrical resistivity values (130-600 $\Omega \mathrm{m})$ in the uppermost parts of the ERT profiles can be explained by a low water content and low compaction of the youngest debris-flow deposit DF-3, which has a coarser grained sandy to silty matrix (Fig. 5c).

\section{Shear wave seismic profile}

The shear wave seismic profile was acquired and interpreted to image the near surface structure of the Harz Boundary
Fault (Fig. 9). The location of the seismic profile is shown in Figs. 1c and 4.

The profile runs roughly NE-SW and crosses the Harz Boundary Fault and the steeply dipping Palaeozoic-Mesozoic rocks of the foreland (Figs. 1c, 9a, b). It is approximately $1 \mathrm{~km}$ long and was acquired $500 \mathrm{~m} \mathrm{SE}$ of the sinkhole (Figs. 1c, 4).

The steeply dipping, almost vertically oriented Permian and Triassic rocks represent a special challenge for seismic imaging. The $70^{\circ}$ limit of the applied FD-migration (Yilmaz 1987 ) results in a limitation of the reflection seismic method to image steeply dipping structures. Due to the survey geometry, the vertical to steeply dipping beds north of the Harz Boundary Fault are not directly imaged. The fault traces and lithological units are interpreted based on reflector disruptions and secondary wavelet effects caused by changes in signature patterns.

\section{Seismic facies (SF)}

Six different seismic facies (SF) can be distinguished in the seismic profile. These different seismic facies are characterized by using the external geometry and the internal reflector pattern (Fig. 10).

\section{Seismic facies 1}

SF-1 is characterized by mainly horizontal to sub-horizontal parallel, continuous to partly discontinuous reflectors. Locally high-amplitude reflectors are developed and partly the reflectors are transparent. In the upper part, the parallel reflectors are more continuous and locally dip in two directions and form a slightly curved pattern.

\section{Interpretation}

Based on the geological map of the study area, the parallel reflectors with higher amplitudes are interpreted as Carboniferous sandstones (cf. Schröder et al. 1927). Parts of the shallower dipping Carboniferous sandstones produce a clear reflector pattern that can be interpreted following the standard seismic interpretation workflow (e.g., Brandes et al. 2011). The changes in impedance are a result of bedding planes and fractures.

\section{Seismic facies 2}

SF-2 is characterized by short discontinuous, thick and hummocky, partly weak to diffuse, and transparent low-partly high-amplitude reflectors. 

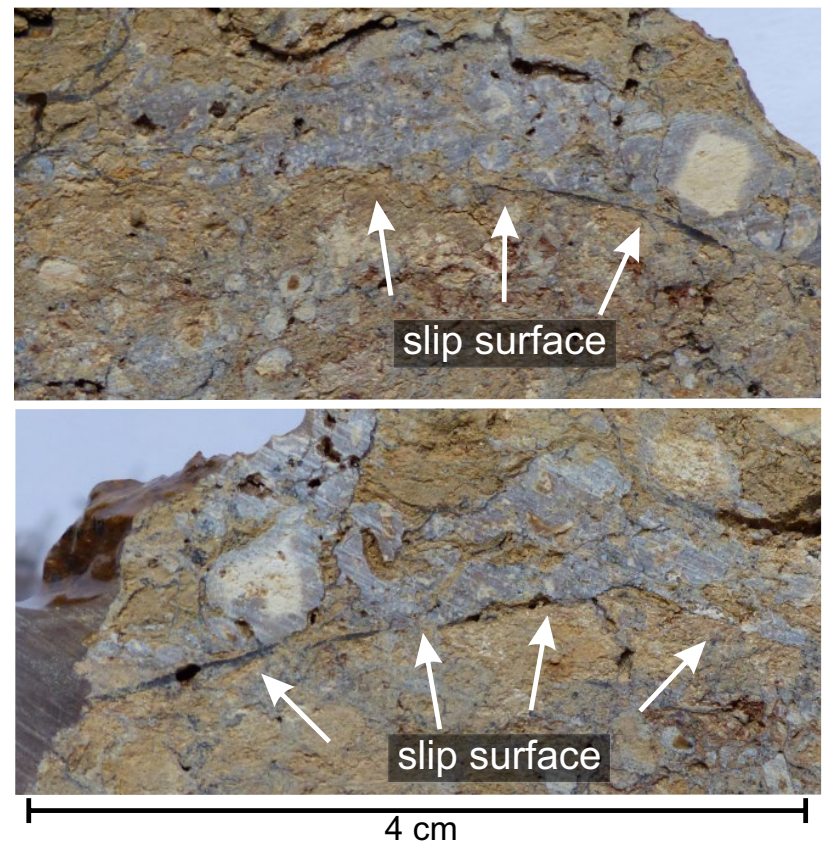

Fig. 7 Cross-section of the fault core material with slip surfaces

\section{Interpretation}

The reflector pattern is characteristic for soluble Permian Zechstein rocks (e.g., Wadas 2016) interpreted as steeply dipping Zechstein sulphates (cf. Schröder et al. 1927) north of the Harz Boundary Fault.

\section{Seismic facies 3}

SF-3 is characterized by short hummocky, thick partly weak to diffuse discontinuous mostly high-amplitude reflectors.

\section{Interpretation}

SF-3 represents the steeply dipping sedimentary rocks of the Buntsandstein north of the Harz Boundary Fault (cf. Schröder et al. 1927). Lithological changes within the Buntsandstein rocks, e.g., the intercalated Rogenstein zone $(\sim 820-785 \mathrm{~m}$ on the profile) produced the different reflector pattern.

\section{Seismic facies 4}

SF-4 has a sheet-like external geometry and an internal mainly parallel, discontinuous to partly continuous closely spaced reflector pattern. Some of the reflectors are weak-toslightly transparent. The lower boundary is erosive.
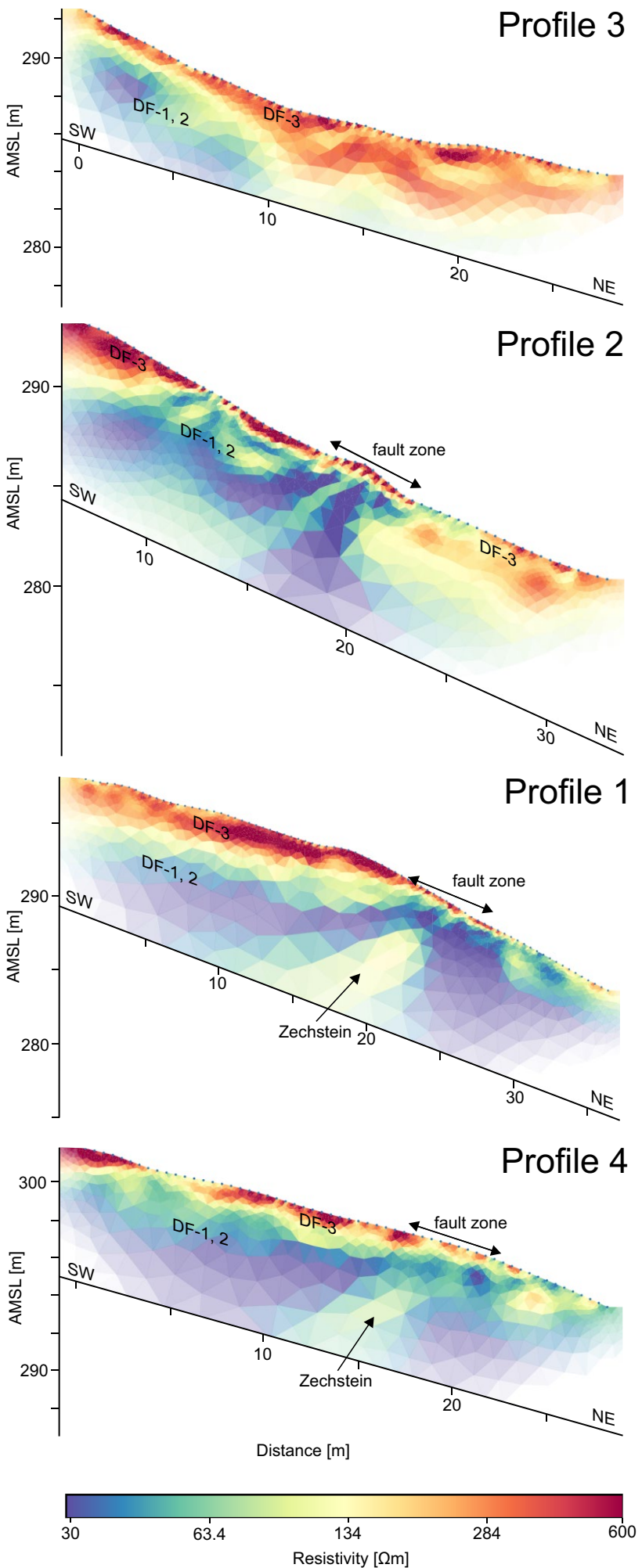

Fig. 8 Measured ERT profiles. For location see Fig. 4. DF-1-DF-3 refer to debris-flow deposits exposed in the sinkhole (Fig. 3). Note that the alpha shading represents the coverage (sum of absolute sensitivity values) and thus indicates the reliability of the structures 


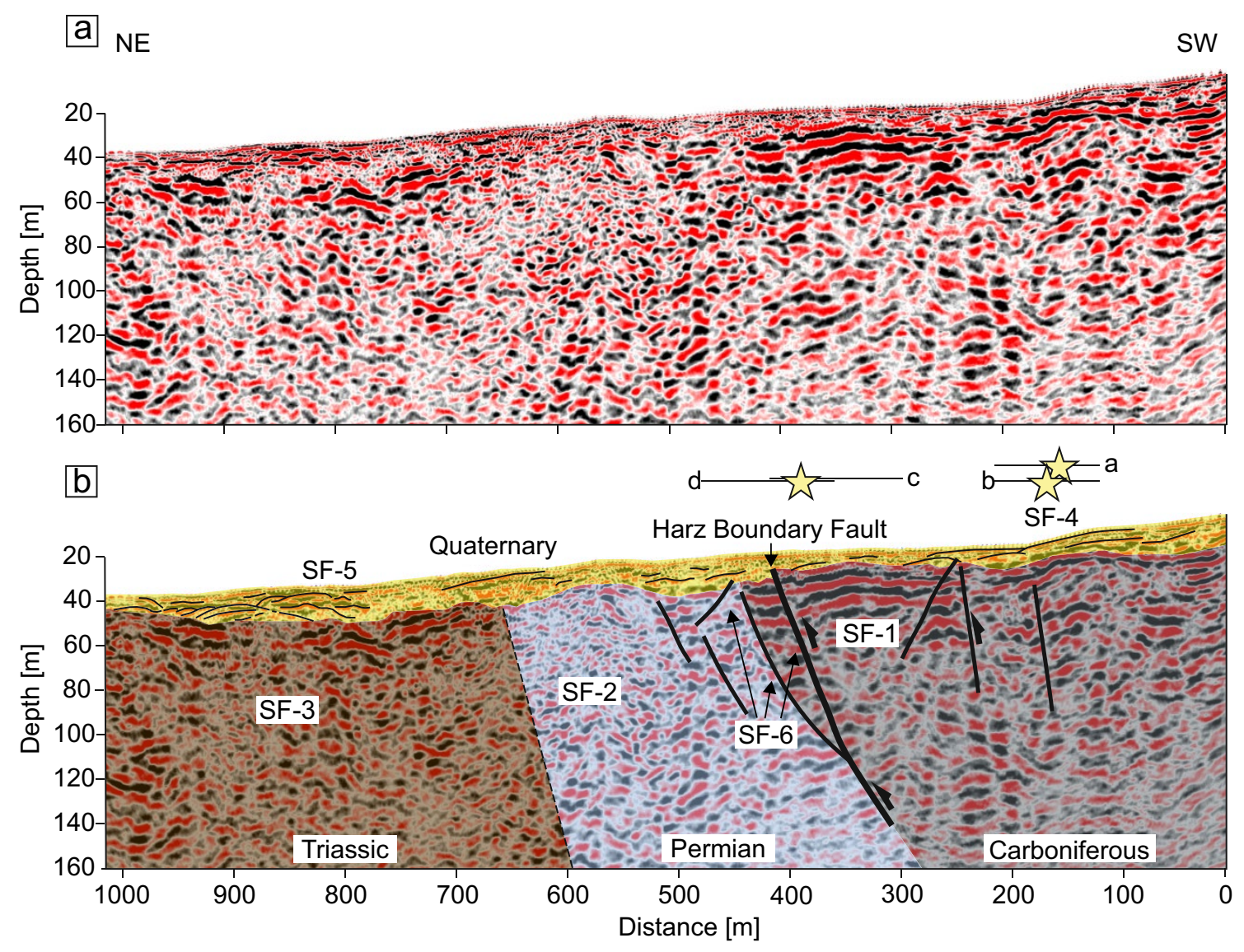

Fig. 9 Shear wave seismic profile. For location see Figs. 1c and 4; a uninterpreted section; b interpreted section. The yellow stars show the shot point locations (a-d) shown in Fig. 13

\section{Interpretation}

Based on the information taken from geological maps (Schröder et al. 1927) and regional stratigraphic studies (Bode et al. 2003) the closely spaced reflector pattern represents proximal Pleistocene alluvial-fan deposits. The sheet-like, slightly inclined geometry points to fan-head aggradation that resulted either from unchanneled debrisflow or stream-flow depositions (cf. Blair and McPherson 2009; Ventra and Nichols 2014; Franke et al. 2015).

\section{Seismic facies 5}

SF-5 has a mound-shaped external geometry and an internal concentric, mainly continuous to partly transparent reflector pattern. These mounds have a width of 20-100 m and are 3-13 $\mathrm{m}$ thick. They show an upslope-stepping, shingled stacking pattern that onlaps seismic facies SF-4. The lower boundary is characterized by partly discontinuous, slightly transparent and concave reflectors.

\section{Interpretation}

The mound-shaped geometry of these deposits points to a mid- or lower fan-environment, where depositional lobes were deposited below the intersection point from stream-flows, sheetfloods or debris-flows. The downslope deposition indicates a phase of fan progradation (cf. Blair and McPherson 2009; Meinsen et al. 2014; Franke et al. 2015). The upslope-stepping lobes may indicate a subsequent phase of aggradation and fan-trench backfilling (e.g., Ventra and Nichols 2014; Meinsen et al. 2014).

\section{Seismic facies 6}

SF-6 is characterized by mainly discontinuous short, subparallel high amplitude reflectors that show a regular offset pattern. 


\section{Seismic} facies

SF-1

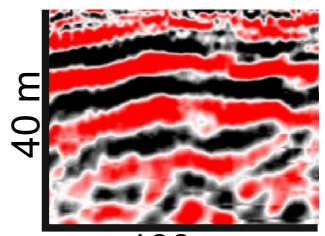

$100 \mathrm{~m}$

SF-2

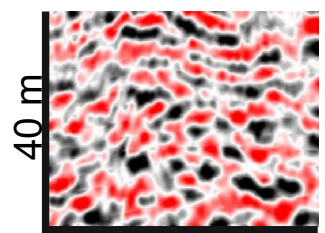
$100 \mathrm{~m}$

SF-3

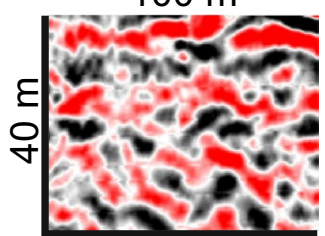

$100 \mathrm{~m}$

SF-4

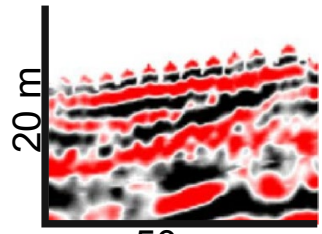

$50 \mathrm{~m}$

SF-5

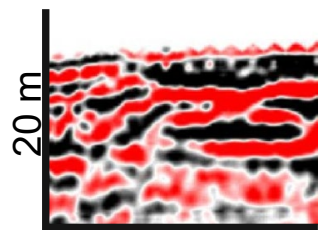

$50 \mathrm{~m}$

SF-6

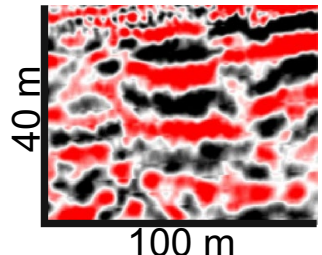

\section{Description}

Parallel to sub-horizontal, continuous to partly discontinuous partly transparent, partly high-amplitude reflectors

Short hummocky, discontinuous, partly weak to diffuse and transparent, lowpartly high-amplitude reflectors

Short hummocky, discontinuous, thick, partly weak to diffuse, mostly highamplitude reflectors

Mainly parallel, discontinuous to partly continuous slightly transparent closely spaced, high-amplitude reflectors

Shingled mound-shaped internal concentric, mainly continuous to partly transparent, partly high-amplitude reflectors

Regular offset pattern of mainly subparallel high-amplitude reflectors

\section{Geological interpretation}

Carboniferous sandstones
Buntsandstein sand- and limestones

Quaternary proximal alluvial-fan deposits deposits

Faults

Fig. 10 Description and interpretation of the seismic facies

\section{Interpretation}

The reflectors result from density variations within the steeply dipping rocks of the Harz Mountain foreland. Their discontinuous, short reflectors with the characteristic offset pattern points to displaced density variations in the subsurface and are, therefore, interpreted as faults (cf. Wadas et al. 2016).

\section{Larger scale subsurface architecture and fault systems}

The visualization of the subsurface structure and the fault system is largely based on the shear wave profile (Fig. 9). The profile crosses the Harz Boundary Fault and covers parts of the foreland. To determine the vertical resolution of this seismic profile, the dominating frequencies were extracted from CMP 300-700 and 1300-1700 down 

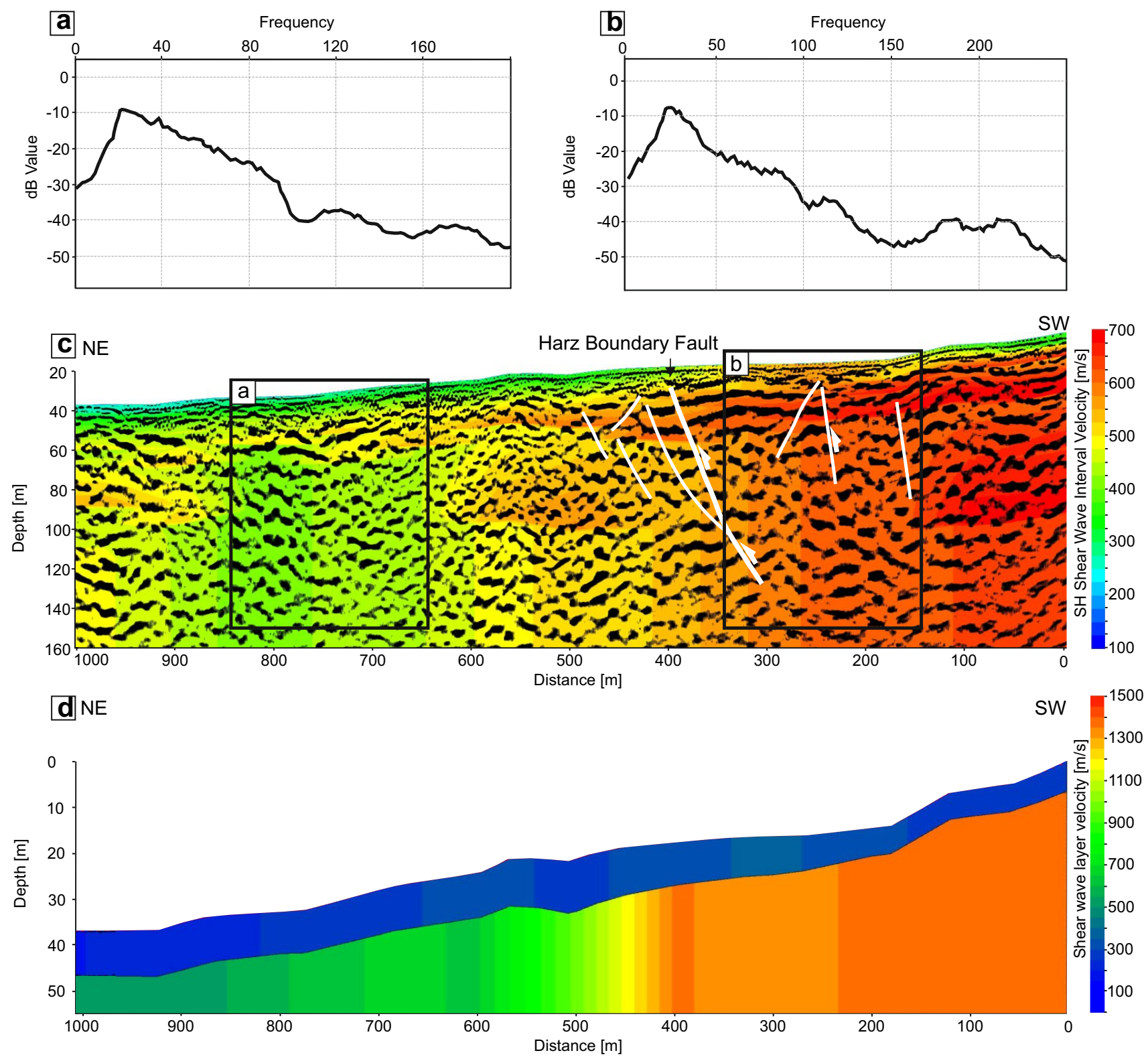

Fig. 11 Local average amplitude spectra of the corresponding time section, shear wave interval velocities and shear wave refraction inversion results. a, b Two extracted average amplitude spectra of the corresponding time section visualize the lateral change in the frequency response in the time range $0-500 \mathrm{~ms}$ TWT, which corresponds to a depth range of $\sim 0-150 \mathrm{~m}$. The dominating frequencies $(\sim 30 \mathrm{~Hz})$ extracted from window a CMP range 300-700 and corresponding shear wave velocities of $\sim 600 \mathrm{~m} / \mathrm{s}$ result in a vertical resolution of $\sim 5 \mathrm{~m}$; b CMP range 1300-1700 and shear wave velocities of $\sim 450 \mathrm{~m} / \mathrm{s}$ result in a vertical resolution of $\sim 4 \mathrm{~m}$; c colour-coded seismic profile by shear wave interval velocities derived from reflection seismic stacking velocities. The lateral variations in velocities image the response of the lateral succession of steeply dipping rock units. Due to the averaging of the incoming and outgoing raypath velocity at a vertical velocity boundary of different rock units by the CMP ray fan methodology, these boundaries are not imaged in a precise, sharp manner, only the change of the average values along a vertical boundary are imaged; $\mathbf{d}$ results of the shear wave refraction inversion for a two-layer model (one layer above the half-space) based on the first break pick times of all seismic traces recorded. The upper layer represents the poorly consolidated Quaternary alluvialfan deposits and the weathering zone of the rocks; the lower layer represents the bedrock (half space). The colour coding shows the calculated refraction layer velocities, which are varying from 200 to $350 \mathrm{~m} / \mathrm{s}$ for the upper layer, and from $1500 \mathrm{~m} / \mathrm{s}$ (SW) to $516 \mathrm{~m} / \mathrm{s}$ (NE) for the half space 
to $500 \mathrm{~ms}$ TWT, which represents approximately a depth of $0-150 \mathrm{~m}$ (Fig. $11 \mathrm{a}-\mathrm{c}$ ). The extracted frequencies are in a range of $30 \mathrm{~Hz}$. For the $\mathrm{SW}$ part of the profile the frequency of $30 \mathrm{~Hz}$, together with shear wave velocities of $600 \mathrm{~m} / \mathrm{s}$ cause wavelengths of approximately $20 \mathrm{~m}$ and a resulting vertical resolution of about $5 \mathrm{~m}$. In the NE part of the seismic profile, the shear wave velocities are lower with about $450 \mathrm{~m} / \mathrm{s}$, which results in a local vertical resolution of about $4 \mathrm{~m}$. This is sufficient for the visualization of the structural elements related to the Harz Boundary Fault.

The seismic profile displays six different seismic facies. The lower seismic units comprise seismic facies $1-3$, representing Carboniferous bedrock and steeply dipping Permian and Triassic rocks (Fig. 9a, b; cf. Schröder et al. 1927). SF-1 is located in the SW part $(\sim 0-440 \mathrm{~m})$ of the section. SF-2 occur in the central part ( 440-660 m) and SF-3 in the NE part ( 660-1000 m) of the profile (Fig. 9a, b).

The steeply dipping rocks of partly SF-1, SF-2 and SF-3 do not allow a common analysis of the reflector pattern (cf. Yilmaz 1987). In this case, the reflectors do not represent bedding planes, because the sedimentary succession was strongly tilted during the uplift of the Harz Mountains. The reflections result from lateral changes in the physical properties of the rocks, caused by faults, fractures and small-scale density variations within the individual lithological units (cf. Woolery et al. 1993). The prominent lateral changes in the reflector pattern from low-amplitude discontinuous to higher amplitude discontinuous reflectors indicate the transition from the Upper Permian rocks to the rocks of the Lower to Middle Buntsandstein.

The bedrock is unconformably overlain by $7-17 \mathrm{~m}$ thick Quaternary deposits (Fig. 9a, b), (SF-4 and SF-5) that most probably represent Pleniglacial to Lateglacial alluvial-fan deposits (Fig. 10; cf. Roskosch et al. 2012; Meinsen et al. 2014). SF-4 occurs in the upper $\sim 10 \mathrm{~m}$ at the SW part $(\sim 700-0)$ and SF-5 at the NE part $(\sim 1000-700 \mathrm{~m})$ in the seismic profile (Fig. 9a, b). The stacking pattern indicates a prograding-retrograding fan system, which might have been controlled by changes in water discharge and sediment supply (cf. Meinsen et al. 2014).

SF-6 represents steeply dipping Permian rocks, in which faults displace density variations. These systematic offsets allow to interpret faults on the seismic profile. Comparable structures and interpretations were presented by Wadas et al. (2016) for Permian Zechstein rocks close to Bad Frankenhausen. These faults occur in the SW part of the seismic profile within SF-1 and in a $300 \mathrm{~m}$ wide zone between SF-1 and SF-2 $(\sim 150-500 \mathrm{~m})$. Several synthetic and antithetic reverse faults are mapped that partly propagate into the overlying Late Pleistocene alluvial-fan deposits (SF-4 and SF-5; Fig. 9a, b). These SSW-ward dipping thrusts and NNE-ward dipping faults form a splay fault system, which developed during the Cretaceous inversion phase. It is likely that the fault exposed in the sinkhole is one of these NNE-ward dipping back thrusts (Fig. 9a, b).

The seismic interval velocities (Fig. 11c) image the lithological changes along the seismic profile. The highest velocities in the SW correspond to the Carboniferous sandstones. Between 440 and $270 \mathrm{~m}$, a significant decrease in the shear wave velocity is recorded, which images the transition between the Carboniferous sandstones and the Permian rocks. The floating decrease in the seismic interval velocity is caused by CMP ray velocity averaging and subsequent interpolation effects at the boundaries of the different lithologies and probably by the development of damage zones parallel to the faults of the splay fault system at the Harz Boundary (Figs. 1, 4, 9). The onset of lower shear wave interval velocities at approximately $600 \mathrm{~m}$ (Fig. 11c) images the boundary from the Permian rocks to the Triassic rocks.

The strong lateral change in seismic interval velocities (also referred to as layer inhomogeneity) is supported by the results of the shear wave refraction inversion (Fig. 11d) for a two-layer model (one layer above the half-space). It is only based on the first break pick times (i.e., only one sample of a recorded trace) of all seismic traces recorded, which results in a simplified velocity-depth model. The upper layer represents the Quaternary alluvial-fan deposits and the weathering zone of the rocks and the lower layer represents the bedrocks of the Harz Mountains and the Harz foreland area (also referred to as half space layer). The colour coding shows the calculated refraction layer velocities, which vary from 200 to $350 \mathrm{~m} / \mathrm{s}$ for the upper layer (alluvial-fan deposits), and from $1500 \mathrm{~m} / \mathrm{s}$ in the $\mathrm{SW}$ to $516 \mathrm{~m} / \mathrm{s}$ at the NE section of the profile. The strong velocity drop at about $\sim 400 \mathrm{~m}$ indicates the location of the Harz Boundary Fault system and thus the boundary between the Carboniferous sandstones and the Permian rocks.

\section{Age calculation of the debris-flow deposits}

\section{Basal reddish debris-flow (DF-1)}

Sample (Ben-2) provided reliable luminescence ages. The dose recovery ratios $0.93 \pm 0.01$ for the pulsed $\mathrm{IR}_{50}$ signal and $1.08 \pm 0.01$ for quartz OSL signal close to unity (0.9-1.1; Wintle and Murray 2006) show that the applied SAR protocols were suitable for the $D_{\mathrm{e}}$ measurements.

The pulsed $\mathrm{IR}_{50}$ signal of the fine grain fraction yielded a recycling ratio of $1.04 \pm 0.03$ and the quartz OSL recycling ratio was $1.02 \pm 0.05$. The values are within $10 \%$ of unity (cf. Wintle and Murray 2006) and show that the SAR protocol corrected sensitivity changes successfully during the measurements. 
Fading tests gave a mean g-value of $1.4 \pm 0.2 \%$ for the pulsed $\mathrm{IR}_{50}$ signal. The fading uncorrected pulsed $\mathrm{IR}_{50}$ age $(12.8 \pm 0.7 \mathrm{ka})$ was fading corrected based on Huntley and Lamothe (2001). The fading corrected polymineral fine grain age (feldspar) is $14.2 \pm 0.8 \mathrm{ka}$.

The estimated luminescence ages from the reddish debrisflow deposits (Ben-2) for feldspar and quartz are in agreement; $14.2 \pm 0.8 \mathrm{ka}$ (polymineral, feldspar) and $15.2 \pm 0.8 \mathrm{ka}$ (quartz).

\section{Whitish (DF-2) and yellowish debris-flow deposits (DF-3)}

No IRSL signal could be detected by measurements of the polymineral fine grain fraction of samples Ben-3-7. Although the natural OSL signal of Ben-3-7 was well below the saturation level of the laboratory dose response curve (with $2 \mathrm{D}_{0}$ value $>600 \mathrm{~Gy}$ ), the quartz OSL of these samples was regarded as in saturation. Chapot et al. (2012) showed that although the laboratory OSL dose response curve continued to grow, the natural OSL signal saturated at $\sim 150$ Gy. Therefore, all quartz $D_{\mathrm{e}}$ values $>150$ Gy were considered in saturation. Consequently, the calculated ages of samples Ben-3-7 are minimum ages of the deposits before transport (Table 1) or the samples were insufficiently exposed to daylight prior to deposition, which resulting in age overestimation.

The quartz and fading corrected feldspar ages are listed in Table 1.

\section{Numerical simulations}

The results of the numerical simulations are shown in Fig. 12. The coloured solid lines represent the results for the North-European part of the global ice model ICE-6G and the dashed coloured lines for the ANU-ICE ice history model. The time when $\delta$ CFS becomes positive the
Table 1 Quartz and feldspar luminescence ages from Benzingerode
Fig. 12 Modelling results for a thrust faulting stress regime with the development of the change in Coulomb failure stress at the Harz Boundary Fault over the last $26 \mathrm{ka}$ in a depth of $12.5 \mathrm{~km}$. The simulation was performed with two different ice history models. The solid lines represent the results for the North-European part of the global ice model ICE-6G_C. The second ice history model (dashed lines) is the ANU-ICE ice history model. The first $\mathrm{L}$ is the lithospheric thickness being 90 or $140 \mathrm{~km}$; $\mathrm{U}$ is the upper mantle viscosity with $5 \times 10^{20}$ [520] or $8 \times 10^{20}$ [820] Pa s; the second $\mathrm{L}$ is the lower mantle viscosity with $2 \times 10^{21}$ [221] or $2 \times 10^{22}$ [222] Pa s; GRAND represents a laterally varying upper and lower mantle viscosity model

\begin{tabular}{|c|c|c|c|c|c|c|}
\hline \multirow[t]{2}{*}{ Sample } & \multirow[t]{2}{*}{ Debris-flow } & \multicolumn{2}{|l|}{ Quartz } & \multirow{2}{*}{$\begin{array}{l}\text { Feldspar } \\
D_{\mathrm{e}}(\mathrm{Gy})\end{array}$} & \multirow{2}{*}{$\begin{array}{l}\text { Uncorr } \\
\text { Age (ka) }\end{array}$} & \multirow{2}{*}{$\begin{array}{l}\text { Corr } \\
\text { Age (ka) corr }\end{array}$} \\
\hline & & $D_{\mathrm{e}}(\mathrm{Gy})$ & Age (ka) & & & \\
\hline Ben-2 & DF-1 & $64.3 \pm 0.7$ & $15.2 \pm 0.8$ & $60.5 \pm 0.5$ & $12.6 \pm 0.6$ & $14.2 \pm 0.8$ \\
\hline Ben-3 & DF-2 & $>378 \pm 12$ & $>123 \pm 9$ & - & - & - \\
\hline Ben-4 & DF-2 & $>273 \pm 13$ & $>119 \pm 11$ & - & - & - \\
\hline Ben-5 & DF-3 & $>217 \pm 7$ & $>124 \pm 13$ & - & - & - \\
\hline Ben-6 & DF-3 & $>356 \pm 11$ & $>164 \pm 14$ & - & - & - \\
\hline Ben-7 & DF-3 & $>285 \pm 5$ & $>109 \pm 8$ & - & - & - \\
\hline
\end{tabular}

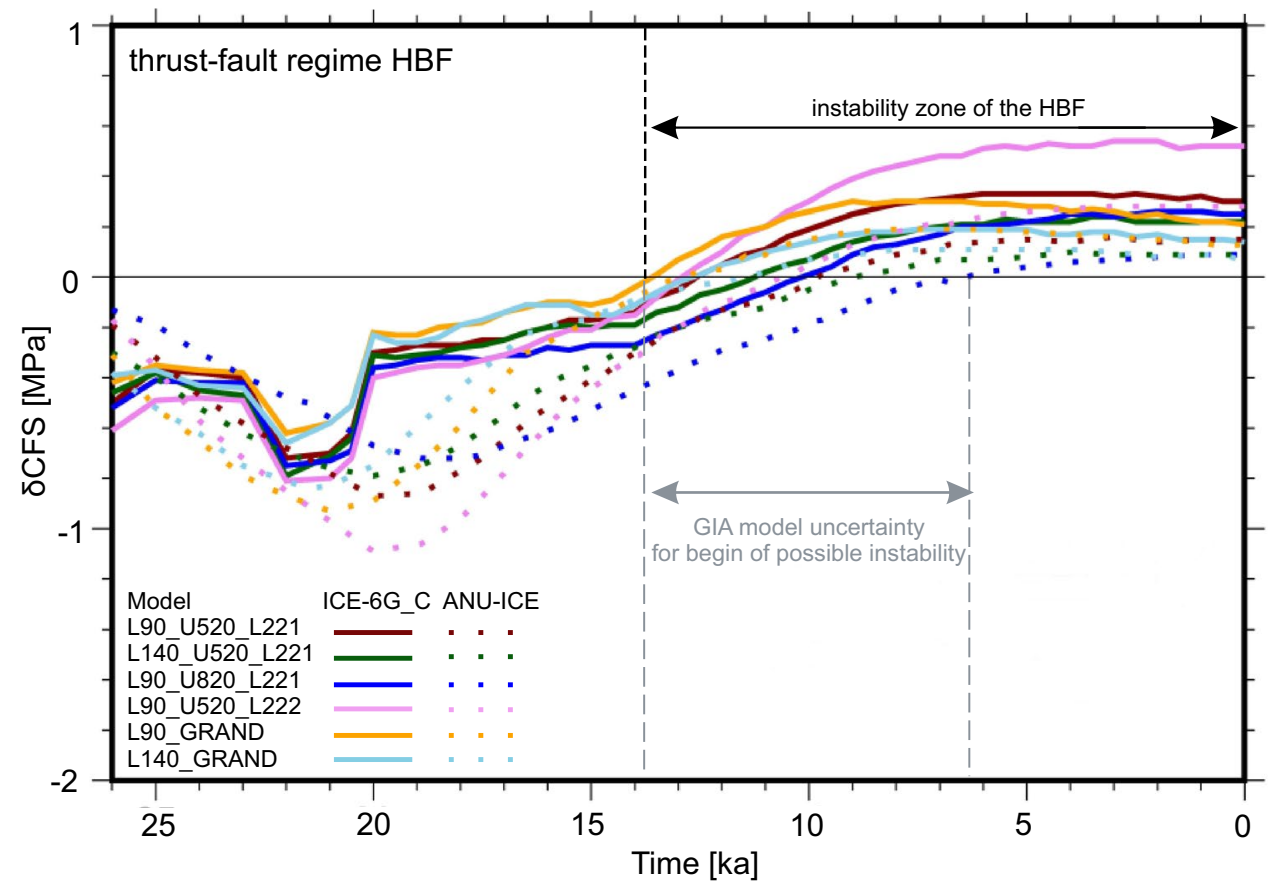


a

Distance [m] 121

Shot point [m]

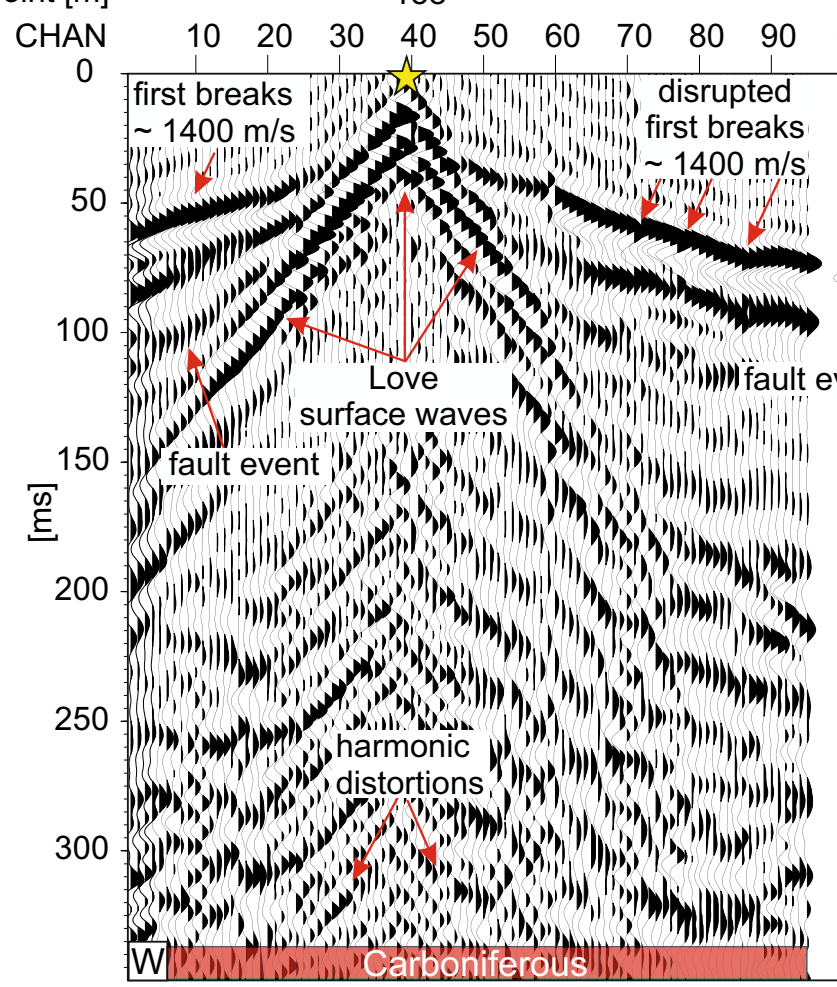

C

Distance [m] 301

Shot point [m]

CHAN $2 \quad 12 \quad 22 \quad 32 \quad 42 \quad 52 \quad 62 \quad 72 \quad 82 \quad 92 \quad 102112$

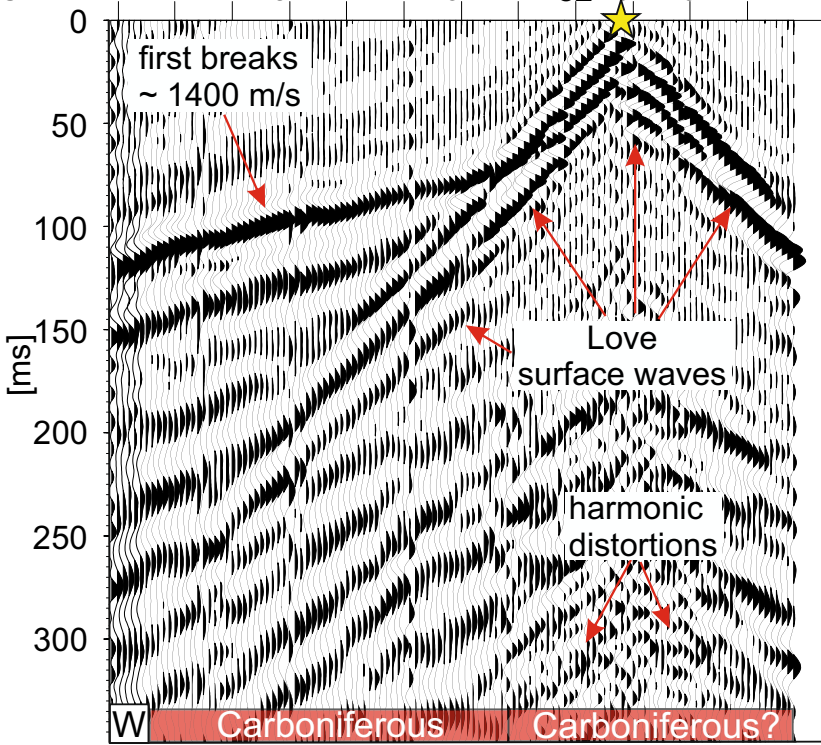

b

$215 \quad 121$

170

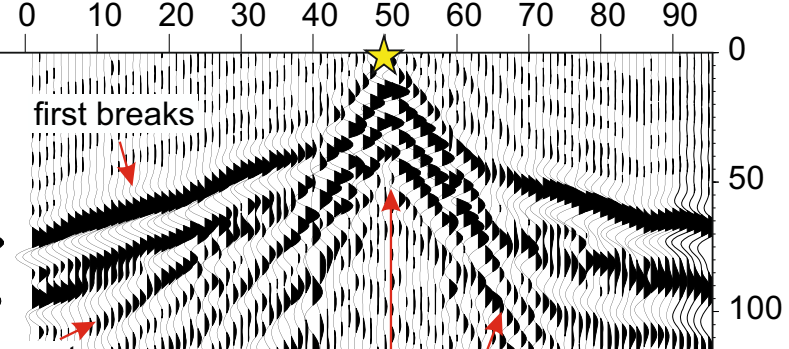

(III,

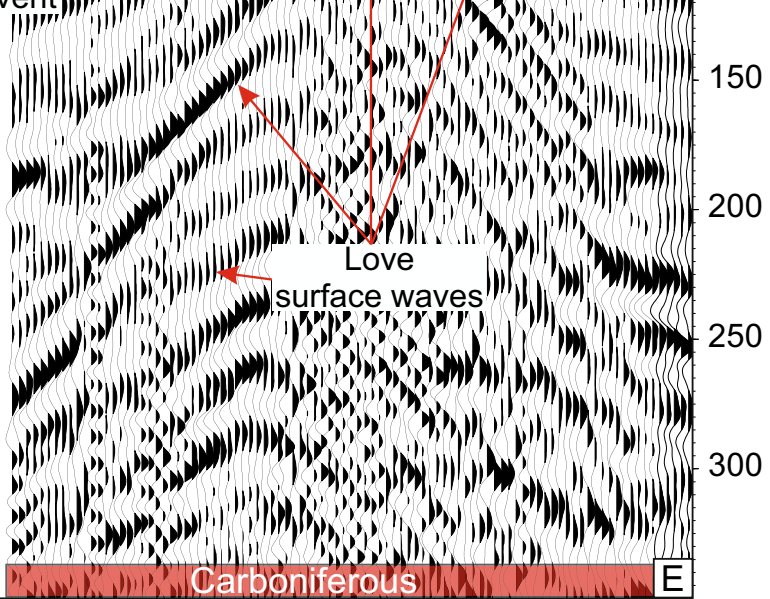

d

420361

480

390

$\begin{array}{lllllllllll}2 & 12 & 22 & 32 & 42 & 52 & 62 & 72 & 82 & 92 & 102112\end{array}$

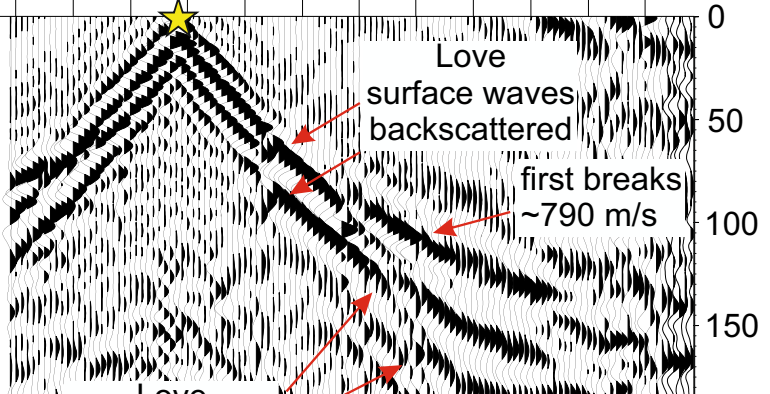

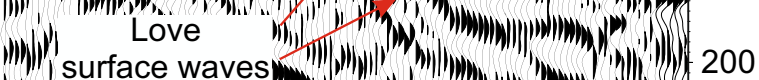

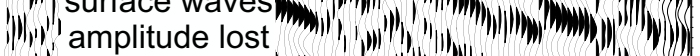

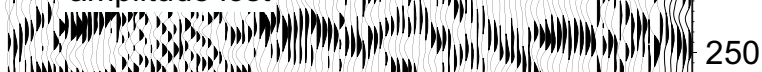
(1) (w) (N)

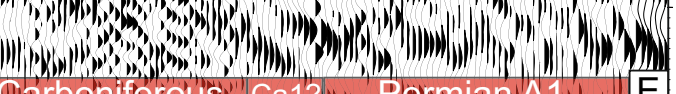


4Fig. 13 Four shot gather examples (vibroseis correlation, automatic gain control $100 \mathrm{~ms}$ window, and bandpass filter 20-22-90-105 Hz applied) along profile meter $121-215$ (a, b), profile meter 301-420 (c) and profile meter $361-480$ (d). Recording duration is $350 \mathrm{~ms}$. Channel numbers and distance along the profile are shown. Individual seismic source locations are labeled by a yellow star. The shot gathers at profile meter $158 \mathrm{~m}$ (a) and $170 \mathrm{~m}$ (b) are located within the Carboniferous sandstones. The high shear wave velocity of nearly $1500-1400 \mathrm{~m} / \mathrm{s}$ is characteristic for these sandstones. Small interruptions are caused by the potential damage zone of the Harz Boundary Fault. A significant drop in the shear wave velocity to $790 \mathrm{~m} / \mathrm{s}$ points to a strong lithological contrast. The refracted waves also give evidence for a thin sliver of Permian Werra dolomite (Ca1) and Permian Werra sulphate (A1) (c, d). Further elements of the surrounding wave field like first breaks, Love surface waves and harmonic distortions are additionally denoted for differentiation. For location of shot point gather examples see Fig. 9b

coloured lines cross the threshold from the stable zone into the unstable zone, which marks the onset of possible fault motion. Due to the relative character of the $\delta$ CFS, it is independent of how large (or small) the positive values of the $\delta$ CFS are.

In a thrust-faulting regime (Fig. 12), the zero line is crossed mainly between 13.8 and $10.3 \mathrm{ka}$ for the ICE6G_C ice model and between 13.2 and $6.3 \mathrm{ka}$ for the ANU-ICE ice model, suggesting that a fault in $12.5 \mathrm{~km}$ depth became instable at that time and was probably reactivated. This timing falls into the deglaciation process of the Late Pleistocene (Weichselian) ice sheet and suggests a fault reactivation triggered by this process.

\section{Discussion}

Central Europe was affected by repeated glaciations since the Middle Pleistocene (Ehlers et al. 2011; Roskosch et al. 2015; Lang et al. 2018). Loading and unloading by ice sheets influenced the lithosphere (Thorson 2000) and resulted in stress modifications (Wu 1997; Stewart et al. 2000), which may lead to the tectonic reactivation of regional fault systems (e.g., Brandes et al. 2011, 2012; Brandes and Winsemann 2013; Brandes et al. 2015, Pisarska-Jamroży et al. 2019).

\section{Structural geology, electrical resistivity tomography and seismic interpretation}

Similar to Franzke et al. (2015), we interpret the fault that is exposed in the sinkhole, as a result of neotectonic activity along the Harz Boundary Fault system. This small fault shows a WNW-ESE strike (Figs. 3, 6) that implies a close connection to the Harz Boundary Fault that has a similar strike as indicated on the geological map (Schröder et al. 1927). This interpretation is supported by the seismic data that show synthetic and antithetic faults (Fig. 9). The seismic profile gives evidence that the Harz Boundary Fault is not a discrete fault but rather represents a splay of several faults. Such a structure is typical for the bounding faults of major basement blocks. Comparable splay fault systems are well known from the Laramide uplifts in the USA (Erslev 1986; Neely and Erslev 2009; Yonkee and Weil 2015). The fault which is exposed in the sinkhole is probably a back thrust of this splay fault system (Fig. 9). Based on the ERT profiles the fault exposed in the sinkhole can be traced for at least $50 \mathrm{~m}$ parallel to the Harz Boundary Fault (Fig. 8).

The fault interpretation shown in Fig. 9b is also supported by the analysis of the refracted shear waves. Based on four shot gather examples (Fig. 13) extracted at profile meter $158 \mathrm{~m}, 170 \mathrm{~m}$ and two at $390 \mathrm{~m}$, the velocity structure is shown. The shot gathers at profile meter 158 and 170 (Fig. 13a, b) are located within the Carboniferous sandstones (cf. Schröder et al. 1927). The documented drop in the shear wave velocity is interpreted as a result of fracturing in a damage zone parallel to a fault. The refracted shear wave in the Carboniferous sandstones with a velocity of up to $1500 \mathrm{~m} / \mathrm{s}(\sim 1400 \mathrm{~m} / \mathrm{s}$ at the position of the shot gathers in Fig. 13) is characterized by small interruptions in the potential damage zone of the Harz Boundary Fault, likely caused by fractures within the Carboniferous rocks (Fig. 13a). The fault interpretation is supported by reflector offsets. We interpret this fault as a branch that is located south of the main fault.

The shear wave velocity of up to $1500 \mathrm{~m} / \mathrm{s}$ (corresponding to a P-wave velocity of $>3000 \mathrm{~m} / \mathrm{s}$ ) is characteristic for the Carboniferous sandstones below the poorly consolidated Pleistocene alluvial-fan deposits (Figs. 11, 13). Compared to the shot gathers shown in Fig. 13a-c the shot gather Fig. $13 \mathrm{~d}$ shows a significant drop in the shear wave velocity to $790 \mathrm{~m} / \mathrm{s}$, which points to a strong lithological contrast. We interpret this as indicator for the position of the main fault, between the high-velocity Carboniferous sandstones and the juxtaposed rather low-velocity Permian rocks.

The refracted shear wave signatures in the shot gather shown in Fig. 13d also give evidence (by the disruption of the first break signature and backscattered Love surface waves) for a thin sliver of Permian Werra dolomite NE of the main fault that is also supported by the results of the shear wave refraction inversion (Fig. 11d, orange to yellow shear wave layer velocity zone at approximately $400-450 \mathrm{~m}$; Fig. 11d).

The results of the seismic refraction inversion (Fig. 11d) allow to delineate the different rock lithologies and match with the interval velocity coded seismic profile (Fig. 11b). Both show a laterally decreasing pattern of high velocities in the SW and lower velocities in the NE, reflecting the lateral succession steeply dipping rock units. 


\section{Timing of fault movements}

The results of luminescence dating show that the age of the lower reddish debris-flow deposit (DF-1) ranges between $14.2 \pm 0.8 \mathrm{ka}$ (feldspar pulsed $\mathrm{IR}_{50}$ ) and $15.2 \pm 0.8 \mathrm{ka}$ (quartz OSL). Since $\mathrm{IR}_{50}$ signal of feldspar bleaches one order of magnitude slower than the quartz OSL, the agreement of ages indicates that both sediments were well bleached before deposition (Murray et al. 2012). The ages imply that fault movements took place after $15 \mathrm{ka}$. The younger yellowish debris-flow deposit (DF-3), that seals the tip of the fault, did not give reliable luminescence ages. The quartz minerals in the sediment are regarded as in saturation. However, it is likely that the uppermost debris-flow deposit is also Lateglacial in age. During the Holocene, a stabilizing vegetation cover rapidly developed on hillslopes most likely preventing erosion and mass movements (cf. Litt et al. 2007; Meinsen et al. 2014).

The age of the alluvial-fan deposits is unknown. Reinecke (2006) assumed a Late Pleniglacial to Lateglacial age for alluvial-fan deposits in the Harz foreland area. The study of Meinsen et al. (2014) from the Senne area implies that the onset of wide-spread alluvial-fan deposition started during the late Middle to Late Pleniglacial $(29.3 \pm 3.2 \mathrm{ka})$ and was probably related to the decreasing temperatures at the end of MIS 3. Strong progradation of alluvial fans correlates with early MIS 2, which is attributed to the decrease of a stabilizing vegetation cover, an increase in water discharge and runoff rates from the catchment areas. The subsequent phase of fan aggradation and retrogradation indicates decreasing discharge and an increase in sediment supply. Fan aggradation in the Senne area ceased at around $19.6 \pm 2.1$ to $18.7 \pm 1.9 \mathrm{ka}$ (Roskosch et al. 2012; Meinsen et al. 2014), when polar desert conditions began to establish, and arid conditions prevailed, resulting in the widespread deposition of aeolian loess, sand-sheets and dunes. This stacking pattern can also be observed in the alluvial-fan deposits of the study area (Seismic profile, SF-4 and 5), pointing to a similar age.

All estimated ages imply a Lateglacial fault activity and would correspond to the time interval of fault reactivation along the Osning thrust and the Sorgenfrei-Tornquist Zone (Brandes et al. 2012, 2018b; Brandes and Winsemann 2013).

\section{Possible trigger for fault development}

\section{Dissolution and migration of Zechstein rocks}

The sinkhole, in which the fault is exposed, developed above steeply dipping sulphate rocks of the Zechstein Werra sequence (Fig. 3). The observed initial normal fault movement could therefore be related to dissolution processes and sinkhole formation (cf. Poppe et al. 2015) or gravitational deformation as a consequence of slope failure (cf. Gardner et al. 1999) and does not require a neotectonic trigger mechanism. Non-tectonic normal faults that were induced by dissolution processes are reported e.g., from SE Utah, (USA) (Guerrero et al. 2015). However, the reverse fault movement, which is indicated on the fault surface by striations cannot be explained by slope failure. Recent experimental studies on sinkhole formation show the development of a set of ring faults (e.g., Poppe et al. 2015). We rule out that the observed fault belongs to such a sinkhole-related ring fault system, because in the sinkhole only one fault is exposed and in a nearby sinkhole (a few $m$ distance), no fault is exposed. Ring faults evolving during the sag process cannot explain the observed evolution of the fault in the sinkhole. In addition, based on ERT profiles and the seismic profile, the lateral extent of the NNE-ward dipping fault was mapped (Figs. 8, 9). The results point to a straight fault that runs parallel to the Harz Boundary Fault. Therefore, we rule out dissolution processes as a driver for fault evolution. Paul (2019) discussed the role of Zechstein salt dissolution and migration for basinwide subsidence in the Harz foreland area. He assumes that no active tectonic uplift of the Harz Mountains has occurred since the Neogene and the apparent relative uplift is caused by subsidence of the foreland basins. As discussed before, we cannot rule out dissolution processes as a potential trigger for normal faulting. However, the two-fold fault kinematics with initial normal faulting followed by reverse and strike-slip movements is difficult to explain with dissolution. Collapse and block rotation processes cannot explain the striations with oblique reverse movement.

We rule out salt migration in the vicinity of the Harz Boundary Fault as proposed by Paul (2019), because crosssections of Baldschuhn et al. (1996) show a salt weld directly north of the range front. The lack of a source layer with a significant thickness makes an effective salt migration unlikely in this part of the Subhercynian Basin.

\section{GIA as possible trigger for fault activity}

Comparable observations of young normal fault movements that were followed by reverse faulting were made by Brandes et al. (2012) and Brandes and Winsemann (2013) at the Osning thrust. The kinematic behaviour is interpreted as a consequence of deformation in the area of the Late Pleistocene Weichselian glacial forebulge. The study area was affected by this forebulge, which was located several $100 \mathrm{~km}$ in front of the ice sheet (Kiden et al. 2002; Nocquet et al. 2005; Busschers et al. 2008; Sirocko et al. 2008; Kierulf et al. 2014; Winsemann et al. 2015). The formation, migration and collapse of the glacial forebulge induced a complex stress pattern in the lithosphere that varied in space and time and could have caused the reactivation of pre-existing faults (cf. Stewart et al. 2000). Moreover, Wu (1997) has shown that GIA can lead to tensional stresses in the forebulge area, with 
values exceeding $10 \mathrm{MPa}$ during full glaciation, although the tectonic background stress regime is thrusting.

The collapse of the forebulge is still ongoing in northern Germany. The recent maximum subsidence rate is $1.0-1.5 \mathrm{~mm} /$ year at latitudes between 50.5 and $53^{\circ} \mathrm{N}$ (Frischbutter, 2001; Nocquet et al. 2005). The tectonic activity along the Harz Boundary Fault system is probably a consequence of the forebulge development and decay, comparable to the similar tectonic evolution as observed at the Osning thrust.

The forebulge area of the older, Middle Pleistocene ice sheets in northern Germany is not exactly known. The Elsterian and Saalian post-glacial re-directions of the rivers Weser and Leine, southwest of the study area, might have been caused by GIA (Winsemann et al. 2015).

With numerical simulations, it is possible to analyse the interplay of glaciation-induced stress changes and fault reactivation (Wu and Hasegawa 1996a, b; Hetzel and Hampel 2005; Turpeinen et al. 2008; Hampel et al. 2009; Steffen et al. 2014b; Hampel 2017). Modelling results of Grollimund and Zoback (2001) and Hampel et al. (2009) imply that post-glacial tectonic activity is possible in areas that are located outside former ice sheets.

Due to the ongoing collision of Europe and Africa, the most suitable results are delivered by a thrust-faulting regime model (Fig. 12), because in parts of northern Germany, recent horizontal compression occurs. The $S_{\mathrm{Hmax}}$ direction shows a fan-like pattern with small deviations from NW to SE in the western regions to NE-SW in the eastern regions (Marotta et al. 2001, 2002, 2004; Kaiser et al. 2005; Heidbach et al. 2016). Hence, based on the thrust-fault regime results, which imply fault activity after $13.8-6.3 \mathrm{ka}$, combined with the results of the luminescence dating of the debris-flow deposit, which imply fault activity after $\sim 15 \mathrm{ka}$, it can be assumed that the reactivation as oblique reverse fault with strike-slip components, is probably triggered by the decay of the Late Pleistocene (Weichselian) ice sheet in the Lateglacial.

Based on field data and numerical simulations, Brandes et al. $(2012$, 2015) showed that the Lateglacial seismicity and the historic earthquakes in northern Central Europe were triggered by stress changes related to GIA. The results of this study imply that the Harz Boundary Fault also underwent a similar reactivation during the decay of the Fennoscandian ice sheet.

\section{Conclusion}

Based on outcrop analyses, luminescence dating, ERT profiles and shear wave seismic data we present new structural data of the Harz Boundary Fault and evidence for GIArelated neotectonic movements in this region. A sinkhole exposes a fault that is most likely related to the Harz Boundary Fault. The shear wave seismic profile shows that the Harz Boundary Fault is a splay fault system in this area. Luminescence dating of faulted debris-flow deposits indicates fault movements after $\sim 15 \mathrm{ka}$. The timing points to movements along the Harz Boundary Fault system as a consequence of stress changes induced by the decay of the Late Pleistocene (Weichselian) Fennoscandian ice sheet. This assumption is supported by numerical simulations of GIA-related change in Coulomb failure stress. Modelling results for a compressional regime assumed for this area show that a possible reactivation of the Harz Boundary Fault was between 13.8 and $6.3 \mathrm{ka}$. This matches with the luminescence dating $(14.2 \pm 0.8$ ka polymineral, feldspar; $15.2 \pm 0.8$ ka quartz), which implies that fault movement occurred after $\sim 15 \mathrm{ka}$ and supports the idea that the Harz Boundary Fault system was reactivated during the Lateglacial. Furthermore, this time of fault movement matches also with data from the Osning thrust and the Sorgenfrei-Tornquist Zone.

Acknowledgements Open Access funding provided by Projekt DEAL. We thank Gösta Hoffmann, Christian Hübscher, Jonas Kley and Klaus Reicherter for their constructive reviews that helped to improve the manuscript. We thank Dieter Epping, Robert Meyer and Jan Bergmann Barrocas for supporting the ERT measurements and Sonja Riemenschneider, Gudrun Drewes, Dr. Yan Li and Petra Posimowski for their help during sample preparation and for supporting the luminescence measurements. The ANU-ICE model parts were kindly provided by Kurt Lambeck and Anthony Purcell.

Open Access This article is licensed under a Creative Commons Attribution 4.0 International License, which permits use, sharing, adaptation, distribution and reproduction in any medium or format, as long as you give appropriate credit to the original author(s) and the source, provide a link to the Creative Commons licence, and indicate if changes were made. The images or other third party material in this article are included in the article's Creative Commons licence, unless indicated otherwise in a credit line to the material. If material is not included in the article's Creative Commons licence and your intended use is not permitted by statutory regulation or exceeds the permitted use, you will need to obtain permission directly from the copyright holder. To view a copy of this licence, visit http://creativecommons.org/licenses/by/4.0/.

\section{References}

Al Hseinat M, Hübscher C (2017) Late Cretaceous to recent tectonic evolution of the North German Basin and the transition zone to the Baltic Shield/southwest Baltic Sea. Tectonophysics 708:28-55

Argus DF, Peltier W, Drummond R, Moore AW (2014) The Antarctica component of postglacial rebound model ICE-6G_C (VM5a) based on GPS positioning, exposure age dating of ice thicknesses, and relative sea level histories. Geophys J Int 198:537-563

Baldschuhn R, Best G, Kockel F (1991) Inversion tectonics in the north-west German basin. Generation, accumulation, and production of Europe's hydrocarbons. Spec Publ Eur Assoc Pet Geosci 1:149-159 
Baldschuhn R, Binot F, Fleig S, Kockel F (1996) Geotektonischer Atlas von Nordwest-Deutschland und dem deutschen Nordsee-Sektor. Geol Jb A 153:3-95

Blair TC, McPherson JG (2009) Processes and forms of alluvial fans. In: Parsons AJ, Abrahams AD (eds) Geomorphology of desert environments, 2nd edn. Springer, Netherlands, pp 413-467

Bock G, Wylegalla K, Stromeyer D, Grünthal G (2002) The Wittenburg $M_{\mathrm{w}}=3.1$ earthquake of May 19th, 2000: an unusual tectonic event in northeastern Germany. In: Korn M (ed), Ten years of German regional seismic network (GRSN). Report 25 of the Senate Commission for Geosciences, Wiley-VCH, pp 220-226

Bode R, Lehmkuhl F, Reinecke V, Hilgers A, Dresely V, Radtke U (2003) Holozäne fluviale Geomorphodynamik und Besiedlungsgeschichte in einem kleinen Einzugsgebiet am nördlichen Harzrand. E\&G Quat Sci J 53:74-93

Brandes C, Tanner D (2012) Three-dimensional geometry and fabric of shear deformation bands in unconsolidated Pleistocene sediments. Tectonophysics 518-521:84-92

Brandes C, Winsemann J (2013) Soft sediment deformation structures in NW Germany caused by Late Pleistocene seismicity. Int J Earth Sci 102:2255-2274

Brandes C, Polom U, Winsemann J (2011) Reactivation of basement faults: interplay of ice-advance, glacial lake formation and sediment loading. Bas Res 23:53-64

Brandes C, Winsemann J, Roskosch J, Meinsen J, Frechen M, Tanner DC, Steffen H, Wu P (2012) Activity along the osning thrust in Central Europe during the late glacial: ice-sheet and lithosphere interactions. Quat Sci Rev 38:49-62

Brandes C, Schmidt C, Tanner DC, Winsemann J (2013) Paleostress pattern and salt tectonics within a developing foreland basin (northwestern Subhercynian Basin, northern Germany). Int J Earth Sci 102:2239-2254

Brandes C, Steffen H, Steffen R, Wu P (2015) Intraplate seismicity in northern Central Europe is induced by the last glaciation. Geology 43:611-614

Brandes C, Igel J, Loewer M, Tanner DC, Lang J, Müller K, Winsemann J (2018a) Visualisation and analysis of shear-deformation bands in unconsolidated Pleistocene sand using groundpenetrating radar: implications for paleoseismological studies. Sediment Geol 367:135-145

Brandes C, Steffen H, Sandersen PBE, Wu P, Winsemann J (2018b) Glacially induced faulting along the NW segment of the Sorgenfrei-Tornquist Zone, northern Denmark: implications for neotectonics and Lateglacial fault-bound basin formation. Quat Sci Rev 189:149-168

Bullmann H (2010) Eigenschaften und Genese periglazialer Deckschichten auf Carbonatgesteinen des Muschelkalks in einem Teilgebiet der ostthüringischen Triaslandschaft. Dissertation, Universität Leipzig, p 283

Busschers FS, Van Balen RT, Cohen KM, Kasse C, Weerts HJT, Wallinga J, Bunnik FPM (2008) Response of the RhineMeuse fluvial system to Saalian ice-sheet dynamics. Boreas 37:377-398

Caputo R, Piscitelli S, Oliveto A, Rizzo E, Lapenna V (2003) The use of electrical resistivity tomographies in active tectonics: examples from the Tyrnavos Basin, Greece. J Geodyn 36:19-35

Chapot MS, Roberts HM, Duller GAT, Lai ZP (2012) A comparison of natural-and laboratory-generated dose response curves for quartz optically stimulated luminescence signals from Chinese Loess. Radiat Meas 47:1045-1052

Cohen KM, Gibbard PL (2019) Global chronostratigraphical correlation table for the last 2.7 million years, version 2019 QI-500. Quat Int 500:20-31

Crawford JM, Doty WEN, Lee MR (1960) Continuous signal seismograph. Geophysics 25:95-105
Dahm T, Heimann S, Funke S, Wendt S, Rappsilber I, Bindi D, Plenefisch T, Cotton F (2018) Seismicity in the block mountains between Halle and Leipzig, Central Germany: centroid moment tensors, ground motion simulation, and felt intensities of two $M \approx 3$ earthquakes in 2015 and 2017. J Seismol 22:985-1003

Döhler S, Terhorst B, Frechen M, Zhang J, Damm B (2018) Chronostratigraphic interpretation of intermediate layer formation cycles based on OSL-dates from intercalated slope wash sediments. CATENA 162:278-290

Drahor MG (2019) Identification of gypsum karstification using an electrical resistivity tomography technique: the case-study of the Sivas gypsum karst area (Turkey). Eng Geol 252:78-98

Dziewonski AM, Anderson DL (1981) Preliminary reference Earth model. Phys Earth Planet Int 25:297-356

Ehlers J, Grube A, Stephan HJ, Wansa S (2011) Pleistocene glaciations of North Germany-new results. In: Ehlers J, Gibbard PL, Hughes PD (eds) Quaternary glaciations: extent and chronology - a closer look: developments in Quaternary Science, 1st edn, 15:149-162

Elsner H (2003) Verbreitung und Ausbildung Elster-zeitlicher Ablagerungen zwischen Elm und Flechtinger Höhenzug. E\&G Quat Sci J 52:91-116

Erslev EA (1986) Basement balancing of Rocky Mountain foreland uplifts. Geology 14:259-262

von Eynatten H, Voigt T, Meier A, Franzke HJ, Gaupp R (2008) Provenance of Cretaceous clastics in the Subhercynian Basin: constraints to exhumation of the Harz Mountains and timing of inversion tectonics in Central Europe. Int J Earth Sci 97:1315-1330

Faulkner DR, Mitchell TM, Jensen E, Cembrano J (2011) Scaling of fault damage zones with displacement and the implications for fault growth processes. J Geophys Res 116:B05403

Feldmann L (2002) Das Quartär zwischen Harz und Allertal mit einem Beitrag zur Landschaftsgeschichte im Tertiär. Clausth Geowiss, vol, 1. pp 1-149

Flick H (1986) The Hercynian Mountains-a postorogenic overthrusted Massif? Naturwissenschaften 73:670-671

Franke D, Hornung J, Hinderer M (2015) A combined study of radar facies, lithofacies and three-dimensional architecture of an alpine alluvial fan (Illgraben fan, Switzerland). Sedimentology 62:57-86

Franzke HJ, Schmidt D (1995) Die mesozoische Entwicklung der Harznordrandstörung-Makrogefügeuntersuchungen in der Aufrichtungszone. Zbl Geol Paläont 1:1443-1457

Franzke HJ, Voigt T, von Eynatten H, Brix MR, Burmester G (2004) Geometrie und Kinematik der Harznordrandstörung, Erläutert an Profilen aus dem Gebiet von Blankenburg. Geowiss Mitt Thüringen 11:39-62

Franzke HJ, Hauschke N, Hellmund M (2015) Spät Pleistozäne bis früh Holozäne Tektonik in einem Karsttrichter im Bereich der Störungszone des Harznordrandes nahe Benzingerode (SachsenAnhalt). Hall JB Geowiss 37:1-10

Frischbutter A (2001) Recent vertical movements (map 4). Brand Geowiss Beitr 8:27-31

Gardner JV, Prior DB, Field ME (1999) Humboldt slide-a large sheardominated retrogressive slope failure. Mar Geol 154:323-338

Gélis C, Revil A, Cushing ME, Jougnot D, Lemeille F, Cabrera J, De Hoyos A, Rocher M (2010) Potential of electrical resistivity tomography to detect fault zones in limestone and argillaceous formations in the experimental platform of Tournemire, France. Pure Appl Geophys 167:1405-1418

Ghose R, Brouwer J, Nijhof V (1996) A portable S-wave vibrator for high resolution imaging of the shallow subsurface. In: Extended Abstract, 59th EAGE Conference and Technical Exhibition, Amsterdam 
Grand SP, Van Der Hilst RD, Widiyantoro S (1997) Global seismic tomography: a snapshot of convection in the Earth. GSA Today $7: 1-7$

Grollimund B, Zoback MD (2001) Did deglaciation trigger intraplate seismicity in the New Madrid seismic zone? Geology 29:175-178

Grube A (2019a) Palaeoseismic structures in Quaternary sediments of Hamburg (NW Germany), earthquake evidence during the younger Weichselian and Holocene. Int J Earth Sci 108:845-861

Grube A (2019b) Palaeoseismic structures in Quaternary sediments, related to an assumed fault zone north of the Permian PeissenGnutz salt structure (NW Germany) - neotectonic activity and earthquakes from the Saalian to the Holocene. Geomorphology 328:15-27

Guerrero J, Bruhn RL, McCalpin JP, Gutiérrez F, Willis G, Mozafari M (2015) Salt-dissolution faults versus tectonic faults from the case study of salt collapse in Spanish Valley, SE Utah (USA). Lithosphere 7:46-58

Guiter F, Andrieu-Ponel V, de Beaulieu JL, Cheddadi R, Calvez M, Ponel P, Reille M, Keller T, Goeury C (2003) The last climatic cycles in Western Europe: a comparison between long continuous lacustrine sequences from France and other terrestrial records. Quat Int 111:59-74

Günther T, Rücker C, Spitzer K (2006) Three-dimensional modelling and inversion of DC resistivity data incorporating topographyII. Inversion. Geophys J Int 166:506-517

Hampel A (2017) Response of faults to climate-induced changes of ice sheets, glaciers and lakes. Geol Today 33:12-18

Hampel A, Hetzel R, Maniatis G, Karow T (2009) Three-dimensional numerical modeling of slip rate variations on normal and thrust fault arrays during ice cap growth and melting. J Geophys Res 114:B08406. https://doi.org/10.1029/2008JB006113

Heidbach O, Rajabi M, Reiter K, Ziegler M, WSM Team (2016) World Stress Map Database Release 2016. V. 1.1. GFZ Data Services. https://doi.org/10.5880/WSM.2016.001

Hetzel R, Hampel A (2005) Slip rate variations on normal faults during glacial-interglacial changes in surface loads. Nature 435:81-84

Hoffmann G, Reicherter K (2012) Soft-sediment deformation of Late Pleistocene sediments along the southwestern coast of the Baltic Sea (NE Germany). Int J Earth Sci 101:351-363

Hübscher C, Lykke-Andersen H, Hansen MB, Reicherter K (2004) Investigating the structural evolution of the western Baltic. Eos Trans AGU 85:115-115

Huijzer B, Vandenberghe J (1998) Climatic reconstruction of the Weichselian Pleniglacial in northwestern and central Europe. J Quat Sci 13:391-417

Huntley DJ, Lamothe M (2001) Ubiquity of anomalous fading in K-feldspars and the measurement and correction for it in optical dating. Can J Earth Sci 38:1093-1106

Kaiser A (2005) Neotectonic modelling of the North German Basin and adjacent areas - $\mathrm{a}$ tool to understand postglacial landscape evolution? ZDGG 156:357-366

Kaiser A, Reicherter K, Hübscher C, Gajewski D (2005) Variation of the present-day stress field within the North German Basininsights from thin shell FE modeling based on residual GPS velocities. Tectonophysics 397:55-72

Kasse C, Vandenberghe D, De Corte F, Van den Haute P (2007) Late Weichselian fluvio-aeolian sands and coversands of the type locality Grubbenvorst (southern Netherlands): sedimentary environments, climate record and age. J Quat Sci 22:695-708

Kiden P, Denys L, Johnston P (2002) Late Quaternary sea-level change and isostatic and tectonic land movements along the BelgianDutch North Sea coast: geological data and model results. J Quat Sci 17:535-546

Kierulf HP, Steffen H, Simpson MJR, Lidberg M, Wu P, Wang H (2014) A GPS velocity field for Fennoscandia and a consistent comparison to glacial isostatic adjustment models. J Geophys Res 119:6613-6629

Kim YS, Peacock DC, Sanderson DJ (2004) Fault damage zones. J Struct Geol 26:503-517

Kley J, Voigt T (2008) Late Cretaceous intraplate thrusting in central Europe: Effect of Africa-Iberia-Europe convergence, not Alpine collision. Geology 36:839-842

Kley J, Franzke HJ, Jähne F, Krawczyk C, Lohr T, Reicherter K, Scheck-Wenderoth M, Sippel J, Tanner D, van Gent H (2008) Strain and stress. In: Littke R, Bayer U, Gajewski D (eds) Dynamics of complex intracontinental basins: the central European Basin system. Springer, Berlin, Heidelberg, pp 97-124

Kockel F (2003) Inversion structures in Central Europe-Expressions and reasons, an open discussion. Neth J Geosci 82:351-366

Krauß L, Zens J, Zeeden C, Schulte P, Eckmeier E, Lehmkuhl F (2016) A multi-proxy analysis of two loess-paleosol sequences in the northern Harz Foreland, Germany. Palaeogeogr Palaeoclimatol Palaeoecol 461:401-417

Lambeck K (1995) Late Devensian and Holocene shorelines of the British Isles and North Sea from models of glacio-hydro-isostatic rebound. J Geol Soc Lond 152:437-448

Lambeck K, Purcell A, Zhao J, Svensson NO (2010) The Scandinavian ice sheet: from MIS 4 to the end of the last glacial maximum. Boreas 39:410-435

Lang J, Winsemann J, Steinmetz D, Polom U, Pollok L, Böhner U, Serangeli J, Brandes C, Hampel A, Winghart S (2012) The Pleistocene of Schöningen, Germany: a complex tunnel valley fill revealed from 3D subsurface modelling and shear wave seismics. Quat Sci Rev 39:86-105

Lang J, Lauer T, Winsemann J (2018) New age constraints for the Saalian glaciation in northern central Europe: implications for the extent of ice sheets and related proglacial lake systems. Quat Sci Rev 180:240-259

Lang J, Alho P, Kasvi E, Goseberg N, Winsemann J (2019) Impact of Middle Pleistocene (Saalian) glacial lake-outburst floods on the meltwater-drainage pathways in northern central Europe: insights from 2D numerical flood simulation. Quat Sci Rev 209:82-99

Lehmkuhl F, Zens J, Krauß L, Schulte P, Kels H (2016) Loess-paleosol sequences at the northern European loess belt in Germany: distribution, geomorphology and stratigraphy. Quat Sci Rev 153:11-30

Leydecker G (2011) Erdbebenkatalog für Deutschland mit Randgebieten für die Jahre 800 bis 2008. Geol Jb E 59, Hannover, p 198

Leydecker G, Kopera JR (1999) Seismological hazard assessment for a site in Northern Germany, an area of low seismicity. Eng Geol 52:293-304

Litt T, Wansa S (2008) Quartär. In: Bachmann GH, Ehling BC, Eichner R, Schwab M (eds) Geologie von Sachsen-Anhalt, 1st edn. Schweizerbart, Stuttgart, pp 293-325

Litt T, Behre KE, Meyer KD, Stephan HJ, Wansa S (2007) Stratigraphische Begriffe für das Quartär des norddeutschen Vereisungsgebietes. E\&G Quat Sci J 56:7-65

Lohr T, Krawczyk CM, Tanner DC, Samiee R, Endres H, Oncken O, Trappe H, Kukla PA (2007) Strain partitioning due to salt: insights from interpretation of a 3D seismic data set in the NW German Basin. Bas Res 19:579-597

Marotta AM, Bayer U, Scheck M, Thybo H (2001) The stress field below the NE German Basin: effects induced by the Alpine collision. Geophys J Int 144:F8-F12

Marotta AM, Bayer U, Thybo H, Scheck M (2002) Origin of regional stress in the North German basin: results from numerical modeling. Tectonophysics 360:245-264

Marotta AM, Mitrovica JX, Sabadini R, Milne G (2004) Combined effects of tectonics and glacial isostatic adjustment on 
intraplate deformation in central and northern Europe: applications to geodetic baseline analyses. J Geophys Res 109:B01413

Meinsen J, Winsemann J, Roskosch J, Brandes C, Frechen M, Dultz S, Böttcher J (2014) Climate control on the evolution of Late Pleistocene alluvial-fan and aeolian sand-sheet systems in NW Germany. Boreas 43:42-66

Murray AS, Thomsen KJ, Masuda N, Buylaert JP, Jain M (2012) Identifying well-bleached quartz using the different bleaching rates of quartz and feldspar luminescence signals. Radiat Meas 47:688-695

Neely TG, Erslev EA (2009) The interplay of fold mechanisms and basement weaknesses at the transition between Laramide basement-involved arches, north-central Wyoming, USA. J Struct Geol 31:1012-1027

Nocquet JM, Calais E, Parsons B (2005) Geodetic constraints on glacial isostatic adjustment in Europe. Geophys Res Lett 32:L06308

Paul J (2019) Hat sich der Harz im jüngeren Tertiär und Quartär gehoben? Z Dt Ges Geowiss 170:95-107

Peltier W, Argus D, Drummond R (2015) Space geodesy constrains ice age terminal deglaciation: the global ICE-6G_C (VM5a) model. J Geophys Res 120:450-487

Pisarska-Jamroży M, Belzyt S, Börner A, Hoffmann G, Hüneke H, Kenzler M, Obst K, Rother H, Van Loon T (2018) Evidence from seismites for glacio-isostatically induced crustal faulting in front of an advancing land-ice mass (Rügen Island, SW Baltic Sea). Tectonophysics 745:338-348

Pisarska-Jamroży M, Belzyt S, Börner A, Hoffmann G, Hüneke H, Kenzler M, Obst K, Rother H, Steffen H, Steffen R, Van Loon $\mathrm{T}$ (2019) The sea cliff at Dwasieden: soft-sediment deformation structures triggered by glacial isostatic adjustment in front of the advancing Scandinavian ice-sheet. DEUQUA Spec Pub 2:61-67

Polom U, Druivenga G, Grossmann E, Grüneberg S and Rode W (2011) Transportabler Scherwellenvibrator: Deutsches Patent und Markenamt. Patentschrift DE10327757B4

Polom U, Bagge M, Wadas S, Winsemann J, Brandes C, Binot F, Krawczyk CM (2013) Surveying near-surface depocentres by means of shear wave seismics. First Break 31:63-75

Poppe S, Holohan EP, Pauwels E, Cnudde V, Kervyn M (2015) Sinkholes, pit craters, and small calderas: analog models of depletioninduced collapse analyzed by computed X-ray microtomography. Geol Soc Am Bull 127:281-296

Reinecke V (2006) Untersuchung zur jungpleistozänen Reliefentwicklung und Morphodynamik im nördlichen Harzvorland. Aachen Geogr Arb 43:1-170

Roskosch J, Tsukamoto S, Meinsen J, Frechen M, Winsemann J (2012) Luminescence dating of an Upper Pleistocene alluvial fan and aeolian sandsheet complex: the Senne in the Münsterland Embayment, NW Germany. Quat Geochronol 10:94-101

Roskosch J, Winsemann J, Polom U, Brandes C, Tsukamoto S, Weitkamp A, Bartholomäus WA, Henningsen D, Frechen M (2015) Luminescence dating of ice-marginal deposits in northern Germany: evidence for repeated glaciations during the Middle Pleistocene (MIS 12 to MIS 6). Boreas 44:103-126

Schröder H, Dahlgrün F (1927) Erläuterungen zur Geologische Karte von Preußen und benachbarten deutschen Ländern, Blatt 4131 Derenburg. Preußisch Geologisches Landesamt, Berlin, p 81

Schröder H, Fliegel G, Dahlgrün F, Beck G (1927) Geologische Karte von Preußen und benachbarten deutschen Ländern, 1:25.000, Blatt 4131 Derenburg, Preußisch Geologisches Landesamt, Berlin

Shipton ZK, Cowie PA (2003) A conceptual model for the origin of fault damage zone structures in high-porosity sandstone. J Struct Geol 25:333-344

Sirocko F, Reicherter K, Lehné R, Hübscher C, Winsemann J, Stackebrandt W (2008) Glaciation, salt and the present landscape.
In: Littke R, Bayer U, Gajewski D (eds) Dynamics of complex intracontinental basins: the Central European Basin System. Springer, Berlin, Heidelberg, pp 97-124

Stackebrandt W (1986) Beiträge zur tektonischen Analyse ausgewählter Bruchzonen der Subherzynen Senke und angrenzender Gebiete. (Aufrichtungszone, Flechtinger Scholle). Veröff Zent Phys Erde 79, Potsdam, pp 1-81

Steffen H, Kaufmann G, Wu P (2006) Three-dimensional finite-element modeling of the glacial isostatic adjustment in Fennoscandia. Earth Planet Sci Lett 250:358-375

Steffen R, Steffen H, Wu P, Eaton DW (2014a) Stress and fault parameters affecting fault slip magnitude and activation time during a glacial cycle. Tectonics 33:1461-1476

Steffen R, Wu P, Steffen H, Eaton DW (2014b) On the implementation of faults in finite-element glacial isostatic adjustment models. Comput Geosci 62:150-159

Stewart IS, Sauber J, Rose J (2000) Glacio-seismotectonics: ice sheets, crustal deformation and seismicity. Quat Sci Rev 19:1367-1389

Tanner DC, Krawczyk CM (2017) Restoration of the Cretaceous uplift of the Harz Mountains, North Germany: evidence for the geometry of a thick-skinned thrust. Int J Earth Sci 106:2963-2972. https://doi.org/10.1007/s00531-017-1475-8

Thorson RM (2000) Glacial tectonics: a deeper perspective. Quat Sci Rev 19:1391-1398

Turpeinen H, Hampel A, Karow T, Maniatis G (2008) Effect of ice sheet growth and melting on the slip evolution of thrust faults. Earth Planet Sci Lett 269:230-241

Ullrich B, Günther T, Rücker C (2008) Electrical Resistivity Tomography Methods for Archaeological Prospection. In: Posluschny A, Lambers K, Herzog I (eds) Layers of Perception. Proceedings of the 35th International Conference on Computer Applications and Quantitative Methods in Archaeology (CAA) Berlin April 262007

van den Bogaard P (1995) 40Ar/39Ar ages of sanidine phenocrysts from Laacher See Tephra (12,900 year BP): Chronostratigraphic and petrological significance. Earth Planet Sci Lett 133:163-174

Vanneste K, Verbeeck K, Petermans T (2008) Pseudo - 3D imaging of a low-slip-rate, active normal fault using shallow geophysical methods: the Geleen fault in the Belgian Maas River valley. Geophysics 73:B1-B9

Ventra D, Nichols GJ (2014) Autogenic dynamics of alluvial fans in endorheic basins: outcrop examples and stratigraphic significance. Sedimentology 61:767-791

Vermilye JM, Scholz CH (1998) The process zone: a microstructural view of fault growth. J Geophys Res 103:12223-12237

Voigt T, von Eynatten H (2008) Field trip POST2-Syntectonic sedimentation in front of a late Cretaceous growth fault-the Harz Mountains and the adjacent Subhercynian Basin (Germany). In: Excursion Guidebook: 26th Regional Meeting of the International Association of Sedimentologists (IAS) held Jointly with the SEPM-CES Sediment 2008 Meeting, Bochum, Germany, September 1-3 2008, Mecke Druck und Verlag 237:59-94

Voigt T, Wiese F, von Eynatten H, Franzke HJ, Gaupp R (2006) Facies evolution of syntectonic Upper Cretaceous deposits in the Subhercynian Cretaceous Basin and adjoining areas (Germany). ZDGG 157:203-243

Voigt T, von Eynatten H, Kley J (2009) Kommentar zu "Nördliche Harzrandstörung: Diskussionsbeiträge zu Tiefenstruktur, Zeitlichkeit und Kinematik" von Volker Wrede ZDGG 159:293-316. ZDGG 160:93-99

Wadas SH, Polom U, Krawczyk CM (2016) High-resolution shear wave seismic reflection as a tool to image near-surface subrosion structures - a case study in Bad Frankenhausen, Germany. Solid Earth 7:1491-1508 
Weymann HJ (2004) Die mittelpleistozäne Flussentwicklung im nord-östlichen Harzvorland. -Petrographie Terrassenstratigraphie. Geol Beitr Hannover 6:3-116

Weymann HJ, Feldmann L, Bombien H (2005) Das Pleistozän des nördlichen Harzvorlands-eine Zusammenfassung. E\&G Quat Sci J 55:43-63

Winsemann J, Lang J, Roskosch J, Polom U, Böhner U, Brandes C, Glotzbach C, Frechen M (2015) Terrace styles and timing of terrace formation in the Weser and Leine valleys, northern Germany: response of a fluvial system to climate change and glaciations. Quat Sci Rev 123:31-57

Winsemann J, Koopmann H, Tanner DC, Lutz R, Lang J, Brandes C, Gaedicke C (2020) Seismic interpretation and structural restoration of the Heligoland glaciotectonic thrust-fault complex: Implications for multiple deformation during (pre-) Elsterian to Warthian ice advances into the southern North Sea Basin. Quat Sci Rev 227:106068

Wintle AG, Murray AS (2006) A review of quartz optically stimulated luminescence characteristics and their relevance in single-aliquot regeneration dating protocols. Radiat Meas 41:369-391

Woolery EW, Street RL, Wang Z, Harris JB (1993) Near-surface deformation in the New Madrid Seismic zone as imaged by high resolution SH-wave seismic methods. Geophys Res Lett 20:1615-1618

Wrede V (1988) Der nördliche Harzrand-flache Abscherbahn oder wrench-fault-system? Int J Earth Sci 77:101-114

Wrede V (2008) Nördliche Harzrandstörung: Diskussionsbeiträge zu Tiefenstruktur, Zeitlichkeit und Kinematik. ZDGG 159:293-316
Wrede V (2009) Antwort auf den Kommentar von T. Voigt, H. von Eynatten and J. Kley zu "Nördliche Harzrandstörung: Diskussionsbeiträge zu Tiefenstruktur, Zeitlichkeit und Kinematik". ZDGG 160:100-106

Wu P (1997) Effect of viscosity structure on fault potential and stress orientations in eastern Canada. Geophys J Int 130:365-382

Wu P (2004) Using commercial finite element packages for the study of earth deformations, sea levels and the state of stress. Geophys J Int 158:401-408

Wu P, Hasegawa HS (1996a) Induced stresses and fault potential in eastern Canada due to a realistic load: a preliminary analysis. Geophys J Int 127:215-229

Wu P, Hasegawa HS (1996b) Induced stresses and fault potential in Eastern Canada due to a disc load: a preliminary analysis. Geophys J Int 125:415-430

Wu P, Wang H, Steffen H (2013) The role of thermal effect on mantle seismic anomalies under Laurentia and Fennoscandia from observations of Glacial Isostatic Adjustment. Geophys J Int 192:7-17

Yilmaz O (1987) Seismic data processing: Society of Exploration Geophysicists, Tulsa, Oklahoma 2:82-153

Yonkee WA, Weil AB (2015) Tectonic evolution of the Sevier and Laramide belts within the North American Cordillera orogenic system. Earth Sci Rev 150:531-593

Zhao S, Lambeck K, Lidberg M (2012) Lithosphere thickness and mantle viscosity inverted from GPS-derived deformation rates in Fennoscandia. Geophys J Int 190:278-292 